\title{
Bio-Adsorbent Derived from Sewage Sludge Blended with Waste Coal for Nitrate and Methyl Red Removal: Synthesis, Oxidation, Performance and Environmental Consideration
}

\author{
John Longo Masengo \\ University of Witwatersrand \\ Jean Mulopo ( $\nabla$ jean.mulopo@wits.ac.za ) \\ University of Witwatersrand
}

\section{Research Article}

Keywords: Sewage sludge, waste coal, activated carbon, oxidation, APS, adsorption, nitrate, MR.

Posted Date: October 6th, 2021

DOI: https://doi.org/10.21203/rs.3.rs-951001/v1

License: (a) (1) This work is licensed under a Creative Commons Attribution 4.0 International License. Read Full License 


\title{
Bio-adsorbent derived from sewage sludge blended with waste coal for nitrate and methyl red removal: synthesis, oxidation, performance and environmental consideration.
}

\author{
John Longo Masengo ${ }^{1}$, Jean Mulopo ${ }^{1, *}$ \\ School of Chemical and Metallurgical Engineering, University of Witwatersrand, P/Bag 3, \\ Wits, Johannesburg, 2050, South Africa ${ }^{l}$
}

\begin{abstract}
Low-cost bio-adsorbents were synthesized using two types of sewage sludge: $\mathrm{D}$, which was obtained during the dissolved air flotation stage, and $\mathrm{S}$, which was a mixture of primary and secondary sludge from the digestion and dewatering stages. The sewage sludge was mixed with waste coal before being activated with Potassium Hydroxide $(\mathrm{KOH})$ and oxidized with ammonium persulfate (APS). The nitrate and methyl red removal capacities of the synthesized bio-adsorbents were evaluated and compared to those of industrial activated charcoal. The oxidation surface area of bio-adsorbents derived from sludge $\mathrm{S}$ shrank by six fold after modification, while those derived from D only varied narrowly from $312,72 \mathrm{~m}^{2} / \mathrm{g}$ to $282,22 \mathrm{~m}^{2} / \mathrm{g}$, but surface modification had no effect on inorganic composition in either case. The adsorption of nitrate and methyl red (MR) was performed in batch mode, and the removal processes followed the pseudo second order kinetic model and the Langmuir isotherm fairly well. The adsorption capacities of nitrate and $\mathrm{MR}$ were higher at $\mathrm{pH}=2$ and $\mathrm{pH}=4$, respectively. The total nitrate Langmuir adsorption potential was DC-5-750 (26,735 mg/g) > commercial activated carbon (Com-AC) (20,61 mg/g) > DC-55-750M1 (17,06 mg/g), and for MR, Com-AC (196,07 mg/g) > DC-5-750M2 (175 mg/g).
\end{abstract}

Statement of Novelty: This paper examines how the chemical structure of activated carbon derived from sewage sludge and blended with waste coal is altered during the chemical activation process to provide the optimal porous surface for nitrate and methyl red adsorptive remediation. The formation of carboxylic sites or the transformation of oxygen sites to carboxylic sites is the aim of the oxidation process of activated carbon in general. Ammonium peroxydisulfate was chosen because of its ability to oxidize the 
surface without significantly altering the porous structure and increase surface acidity by increasing carboxylic group presence. There are no studies that we are aware of that use ammonium peroxydisulfate to oxidize activated carbon from sewage sludge blended with waste coal

35 Keywords: Sewage sludge, waste coal, activated carbon, oxidation, APS, adsorption, nitrate, MR.

40

*jean.mulopo@swits.ac.za

\section{Introduction}

Sewage sludge is an unavoidable by-product of wastewater treatment plants, with treatment costs accounting for $25 \%$ to $65 \%$ of the overall operating costs [1]. South Africa's population has gradually increased over the last two decades, rising from 48.8 million in 2005 to 51.58 million in 2010 to 57.7 million in 2018, with more than half of the country's population now residing in densely populated urban areas [2]. Rapid population growth, combined with rapid urbanization, has put additional pressure on existing wastewater treatment plant (WWTP) facilities, resulting in increased sewage sludge production. Several lines of evidence demonstrate that dumping waste sludge in landfills is not a long-term sewage sludge management solution. Despite the risk of soil and subsoil contamination, nearly $80 \%$ of wastewater treatment plants continue to discharge sewage sludge at designated sites [3].

55 The South African Department of Water Affairs and Forestry has identified five potential applications for sewage sludge: agriculture (fertilizer), on-site and off-site land application (within and outside WWTP boundaries), thermal management activities (e.g. full or partial combustion of organic solids by incineration), and benign land application [3]. The use of sewage sludge fertilizers is restricted due to the difficulties in meeting quality requirements (faecal coliform cap of $10000 \mathrm{CFU} / \mathrm{g}$ dry, Helminth Ova maximum of one viable ova/g dry, pollution) [3]. As a result of these 
restrictions, large quantities of untreated sludge have accumulated on open fields. South Africa produces 673360 metric tons of sewage sludge annually, of which only about $19 \%$ is recycled and the rest is landfilled, necessitating the development of innovative approaches to reduce sewage sludge emissions [2]. Landfilling as a wastewater treatment residue management alternative poses significant environmental concerns about bacteria, heavy metals, and trace organic pollutants; the same conclusion applies to traditional sea dumping and forestry, both of which are deemed unsustainable [4].

Due to the high cost of industrial activated carbons, research on activated carbon materials extracted from bio-waste, such as olive stones, lemon grass, wall nutshells and pine cones has taken center stage $[5,6,7,8]$ and among these, activated carbon extracted from sewage sludge (SBAC) has shown promise in the adsorption of inorganic elements such as $\mathrm{Ni}, \mathrm{Cu}, \mathrm{Pb}, \mathrm{Cd}$ and $\mathrm{Hg}[1,9,10,11,12,13]$.

However, due to the inorganic composition of raw sewage sludge, SBAC has a low surface area, and increasing porosity by adding richer carbonaceous such as coal, bagasse, and coconut shell may be preferable [ 7,9,11,14,15]. On the other hand, The use of $\mathrm{HCl}$ and $\mathrm{NaOH}, \mathrm{HNO}_{3}$ and $\mathrm{N}, \mathrm{N}-$ Dimethylformamide for the oxidation of SBAC in liquid phase has been reported to increase their adsorption potential by adding surface functionalities groups as shown in Table $1[9,16,17,18]$. An in-depth analysis of the existing body of works, on the other hand, exposes knowledge gaps, such as the fact that very few studies take into account the specific chemical composition of the source materials used. The synthesis of activated carbon from sewage sludge has traditionally been oriented toward particular applications and thus has been more focused on results than on understanding the intrinsic structure within the materials (Table 1). In particular, understanding the adsorption of certain inorganic compounds in aqueous solution by activated carbon requires knowledge of the chemical structure of the activated carbon surface, i.e. determining how the chemical structure of the activated carbon surface is oxidized during the chemical activation process in order to achieve the optimal porous surface. When the source material has been chemically treated, the surface of the activated carbons is normally filled with oxygenated sites and probably amine sites which result in three types of oxides on the surface: acidic, basic, and neutral. Acidic sites increase the hydrophilicity of activated carbon, lower the $\mathrm{pH}$ in aqueous suspension, and increase the negative charge density at the surface, while 
simple sites are primarily of the Lewis form and are associated with -rich regions located at the basal planes [19]. Additional benefits can be obtained by oxidizing activated carbon after the activation phase to induce the formation of oxygen complexes. The oxidation process raises the oxygen content by lowering the electronic density of the basal planes, which lowers the basicity at the surface $[19,20,21]$. The oxidation of activated carbon extracted from sewage sludge blended with coal using ammonium peroxydisulfate $\left[\left(\mathrm{NH}_{4}\right)_{2} \mathrm{~S}_{2} \mathrm{O}_{8}\right]$ is investigated in this paper. In general, the oxidation process is intended to result in the formation of carboxylic sites or the transformation of oxygen sites to carboxylic sites. The choice of ammonium peroxydisulfate is based on its ability to oxidizes the surface without modifying drastically the porous structure and enhance surface acidity by increasing carboxylic group presence [22, 23,24]. To our knowledge, there are no reports on the oxidation of activated carbon from sewage sludge blended with waste coal using ammonium peroxydisulfate. Finally, the oxidized activated carbons are tested for nitrate and MR adsorptive remediation.

Table 1 Literature oxidized activated carbon extracted from sewage sludge (SBAC)

110 and adsorption capacity

\begin{tabular}{|c|c|c|c|c|c|c|c|}
\hline \multirow[t]{2}{*}{ References } & \multirow{2}{*}{$\begin{array}{c}\text { SBAC } \\
\text { State }\end{array}$} & \multicolumn{3}{|c|}{ Modification Conditions } & \multirow{2}{*}{$\begin{array}{c}\mathrm{S}_{\mathrm{BET}} \\
\left(\mathrm{m}^{2} / \mathrm{g}\right)\end{array}$} & \multirow[t]{2}{*}{ pH } & \multirow[t]{2}{*}{ Adsorption } \\
\hline & & $\begin{array}{l}\text { Oxidant } \\
\text { Concentration }\end{array}$ & $\begin{array}{l}\text { Soaking } \\
\text { time }\end{array}$ & Temperature & & & \\
\hline \multirow[t]{5}{*}{ [18] } & Unoxidized & - & - & - & 1003,8 & 4,02 & $\begin{array}{l}\text { Malachite } \\
\text { Green: } \\
269,54 \mathrm{mg} / \mathrm{g}\end{array}$ \\
\hline & \multirow[t]{4}{*}{$\begin{array}{c}\text { Oxidized } \\
\text { (2 stages: } 1 \text { and } \\
2 \text { ) }\end{array}$} & $1: 2 \mathrm{M} \mathrm{HNO}_{3}$ & $1: 3 \mathrm{~h}$ & $1: 60^{\circ} \mathrm{C}$ & \multirow[t]{2}{*}{838,3} & \multirow[t]{2}{*}{3,78} & \multirow[t]{2}{*}{$\begin{array}{l}\text { Malachite } \\
\text { Green: } \\
303,03 \mathrm{mg} / \mathrm{g}\end{array}$} \\
\hline & & 2:- & $3 \mathrm{~h}$ & $2: 300^{\circ} \mathrm{C}$ & & & \\
\hline & & 1: $2 \mathrm{M} \mathrm{H}_{2} \mathrm{SO}_{4}$ & $1: 3 \mathrm{~h}$ & $1: 60^{\circ} \mathrm{C}$ & \multirow[t]{2}{*}{960} & \multirow[t]{2}{*}{3,66} & \multirow[t]{2}{*}{$\begin{array}{l}\text { Malachite } \\
\text { Green: } \\
284,90 \mathrm{mg} / \mathrm{g}\end{array}$} \\
\hline & & 2:- & $3 \mathrm{~h}$ & $2: 300^{\circ} \mathrm{C}$ & & & \\
\hline
\end{tabular}




\begin{tabular}{|c|c|c|c|c|c|c|c|}
\hline \multirow[t]{2}{*}{ [11] } & $\begin{array}{c}\text { Unoxidized } \\
\text { (bagasse/sludge: } \\
1 / 2 \text { ) }\end{array}$ & - & - & - & 804,57 & - & $\mathrm{Pb}^{2+}:-$ \\
\hline & $\begin{array}{c}\text { Oxidized } \\
\text { (bagasse/sludge: } \\
1 / 2 \text { ) }\end{array}$ & $60 \% \mathrm{HNO}_{3}$ & $6 \mathrm{~h}$ & $90^{\circ} \mathrm{C}$ & 69,19 & - & $\begin{array}{l}\mathrm{Pb}^{2+}: 51,3 \\
\mathrm{mg} / \mathrm{g}\end{array}$ \\
\hline \multirow[t]{2}{*}{ [16] } & Unoxidized & - & - & - & 721 & - & $\begin{array}{l}\text { Fluorene: } \\
0,5 \mathrm{mg} / \mathrm{g}\end{array}$ \\
\hline & Oxidized & $\begin{array}{l}10 \mathrm{M} \mathrm{HNO}_{3} \\
1 \mathrm{~g}: 10 \mathrm{ml}\end{array}$ & $4 \mathrm{~h}$ & $90^{\circ} \mathrm{C}$ & 86,1 & - & $\begin{array}{l}\text { Fluorene: } \\
2,8 \mathrm{mg} / \mathrm{g}\end{array}$ \\
\hline \multirow[t]{3}{*}{ [17] } & Unoxidized & - & - & - & 721,2 & - & $\begin{aligned} & \mathrm{Pb}^{2+}: 1,25 \\
& \mathrm{mg} / \mathrm{g}\end{aligned}$ \\
\hline & \multirow[t]{2}{*}{ Oxidized } & $\begin{array}{l}10 \mathrm{M} \mathrm{HNO}_{3} \\
1 \mathrm{~g}: 4 \mathrm{ml}\end{array}$ & $4 \mathrm{~h}$ & $20^{\circ} \mathrm{C}$ & 674,7 & - & $\begin{array}{ll}\mathrm{Pb}^{2+}: & 3,04 \\
\mathrm{mg} / \mathrm{g} & \end{array}$ \\
\hline & & $\begin{array}{l}10 \mathrm{M} \mathrm{HNO}_{3} \\
1 \mathrm{~g}: 10 \mathrm{ml}\end{array}$ & $4 \mathrm{~h}$ & $90^{\circ} \mathrm{C}$ & 86,12 & - & $\begin{array}{l}\mathrm{Pb}^{2+}: 4,05 \\
\mathrm{mg} / \mathrm{g}\end{array}$ \\
\hline
\end{tabular}

\section{Experimental}

\subsection{Materials}

All reagents, including $\mathrm{NaOH}, \mathrm{NaNO}_{3}, \mathrm{KOH}, \mathrm{HCl}(32 \%),\left(\mathrm{NH}_{4}\right)_{2} \mathrm{~S}_{2} \mathrm{O}_{8}$ (APS), $\mathrm{H}_{2} \mathrm{SO}_{4}$, and $\mathrm{NaCl}$, were obtained from Associate Chemical Enterprise (ACE) and were analytical grade. Sigma-Aldrich (SA) supplied activated charcoal (C3014-500G), which was designated Com-AC.

Two forms of sewage sludge namely D and S were collected at the East Rand Water Care Company (ERWAT) wastewater treatment plant facilities. D was collected during 
the dissolved air flotation stage, while $\mathrm{S}$ was a combination of the primary and secondary sludge from the digestion and dewatering stages, respectively.

\subsection{Methods}

Raw sewage sludges were sun dried for 24 hours before being oven-dried. The dried sludge was crushed to $100 \%$ passing through $125 \mu \mathrm{m}$ sieves, and pyrolyzed at different temperatures (DC-5-750, DC-7-900, SC-3-600, and SC-5-900). The products from the pyrolysis were mixed with discard coal in a proportion of 1:1 and activated with $\mathrm{KOH}$ under $\mathrm{N}_{2}$ atmosphere at a flow rate of $5 \mathrm{l} / \mathrm{min}$. To achieve surface modification via oxidation, $1 \mathrm{~g}$ of pyrolyzed sewage sludge was incubated in $25 \mathrm{ml}$ of $1 \mathrm{M}$ or $2 \mathrm{M}$ APS dissolved in $1 \mathrm{M} \mathrm{H}_{2} \mathrm{SO}_{4}$ at $60^{\circ} \mathrm{C}$ for 240 minutes before being washed with distilled water until the $\mathrm{pH}$ neutral value was reached. Batch adsorption experiments were carried out with an adsorbent dose of $0.5 \%$ (5 mg of adsorbent in $10 \mathrm{ml}$ of solution) and the performance of bio-adsorbents was compared to commercial activated carbon. The best oxidized and/or unoxidized SBACs were chosen based on preliminary evaluation test results conducted at $303 \mathrm{~K}$ in an incubator shaker. The initial concentration of nitrate was $50 \mathrm{mg} / \mathrm{l}$, with contact times of 180 and 360 minutes, respectively, while the initial concentration of MR was 75 ppm, with contact times of 90 and 180 minutes, and initial $\mathrm{pH}$ of 2 and 4 for nitrate and methyl red, respectively. The initial $\mathrm{pH}$ value of 2 in the case of nitrate was chosen because adsorbent surfaces are prone to being positively charged as $\mathrm{pH}$ decreases, and nitrate ions cannot compete with hydroxyl anions [25] and $\mathrm{pH} 4$ was chosen in the case of MR to prevent competition with $\mathrm{H}^{+}$ cations while attempting to preserve the adsorbent surface deprotonated [26].

\subsection{Chemical analysis}

SEM and EDS analysis were done using a ZEISS SIGMA FESEM 03- 39 apparatus on coated samples on a carbon tape support using Gold-Palladium techniques. TGA was performed with the Pioneer (SDT-Q500) equipment. Proximate analysis of sewage was performed using a Perkin-Elmer STA 6000 simultaneous thermal analyser. FT-IR 
analyses were done using the Perkin-Elmer FT-IR Spectrometer Spectrum 2. Ultimate analysis was conducted with the thermoscientific flash 2000. XRD study was done using a Bruker 2D phaser instrument with $\mathrm{CuK} \alpha 1$ radiation at a wavelength of 1,54060 $\mathrm{cm}^{-1}$ and a $2 \theta$ angle. The $\mathrm{NH}_{4} \mathrm{OAC}$ method [27] was used to determine cations exchange capacity. The Boehm titration method was used to determine the acidity of SBAC [28]. The $\mathrm{pH}$ point of zero charge was determined using the procedure described by Leng et al. [29]. Surface functionalities and graphitization or carbon disorder structure of the adsorbent were assessed using FT-IR analysis and Raman spectroscopy, respectively. For the $\mathrm{pH}$ point of zero charge, $50 \mathrm{mg}$ of adsorbent were placed in vials with $40 \mathrm{ml}$ of $0,01 \mathrm{M} \mathrm{NaCl}$ solution and shaken for 48 hours, the solution $\mathrm{pH}$ ranged from 2 to 12 with an incremental of 2 . The concentrations of nitrate and MR were calculated using an IC dionex-120 and a U-vis Shimadzu 1800, the latter at a wavelength of $480 \mathrm{~nm}$, as per Ding et al. [30].

\section{Results and discussion}

\subsection{Pretreatment and characterisation of precursors}

The precursors were sun dried, and the moisture content of the sample was determined by mass losses after oven drying at $105^{\circ} \mathrm{C}$ for 24 hours as shown in Table 2 .

Table 2 Non-dried and sun dried sample moisture content

\begin{tabular}{|c|c|c|}
\hline $\begin{array}{c}\text { Types of } \\
\text { sludge }\end{array}$ & $\begin{array}{c}\text { Non-dried sample } \\
\text { Moisture (\%) }\end{array}$ & $\begin{array}{c}\text { Moisture content After sun } \\
\text { drying (\%) }\end{array}$ \\
\hline D & 96,28 & 6,285 \\
\hline S & 85,33 & $7,0.37$ \\
\hline
\end{tabular}

The elemental analysis (Table 3) reveals that there is only a minor difference between the two samples, indicating that digestion has no effect on the organic content of sewage sludge, despite the volatile solid content being slightly different. However, 
although the surface area of sludge from D was approximately $1.5 \mathrm{~m}^{2} / \mathrm{g}$, the surface area of sludge $\mathrm{S}$ could not be determined, possibly due to a lack of porosity in the precursor materials.

Table 3 Precursors properties

\begin{tabular}{|l|l|l|l|}
\cline { 2 - 4 } \multicolumn{1}{c|}{} & \multicolumn{3}{c|}{ Precursors } \\
\cline { 2 - 4 } \multicolumn{1}{c|}{} & $\mathrm{D}$ & $\mathrm{S}$ & Discard coal \\
\hline Elemental analysis & & & \\
\hline $\mathrm{C}(\%)$ & 36.511 & 36,640 & 43,133 \\
\hline $\mathrm{H}(\%)$ & 5,526 & 5,215 & 2,424 \\
\hline $\mathrm{N}(\%)$ & 5,020 & 2,681 & 0 \\
\hline $\mathrm{S}(\%)$ & 2,002 & 2,225 & 2,429 \\
\hline $\mathrm{H} / \mathrm{C}$ & 0,151 & 0,142 & 0,056 \\
\hline N/C & 0,137 & 0,073 & 0 \\
\hline Proximate analysis & & & \\
\hline Fixed carbon $(\%)$ & 4,15 & 4,86 & 15,76 \\
\hline Ash $(\%)$ & 29,15 & 35,98 & 67,96 \\
\hline Volatile $(\%)$ & 66,7 & 59,16 & 16,28 \\
\hline Volatile solid & 2,161 & 1,216 & 1,474 \\
\hline Surface properties & & & \\
\hline S BET $\left(\mathrm{m}^{2} / \mathrm{g}\right)$ & 1,411 & - & 3,848 \\
\hline Pore volume & 0,011 & - & 0,014 \\
\hline Pore size (nm) & 30,72 & - & 15,11 \\
\hline
\end{tabular}

In Figure 1, the TGA curve of dried sludge shows that between $30^{\circ} \mathrm{C}$ and $190{ }^{\circ} \mathrm{C}$, there is a slight mass loss, and the mass of both sludge was roughly $5 \%$, possibly due to adsorbed water. The most mass loss occurred between 200 and 600 degrees Celsius, with mass loss of D and S increasing from about $5 \%$ at 200 degrees Celsius to about two-thirds (64\%) and half (46\%) at 600 degrees Celsius, respectively. The mass loss from $600{ }^{\circ} \mathrm{C}$ to $1000{ }^{\circ} \mathrm{C}$ is less pronounced for both sludge with 17 and $13 \%$ for $\mathrm{D}$ and $\mathrm{S}$ respectively. As a result, $600{ }^{\circ} \mathrm{C}$ was chosen as the minimum temperature for pyrolysis. S appears to be slightly more stable than D based on the TGA curves. 


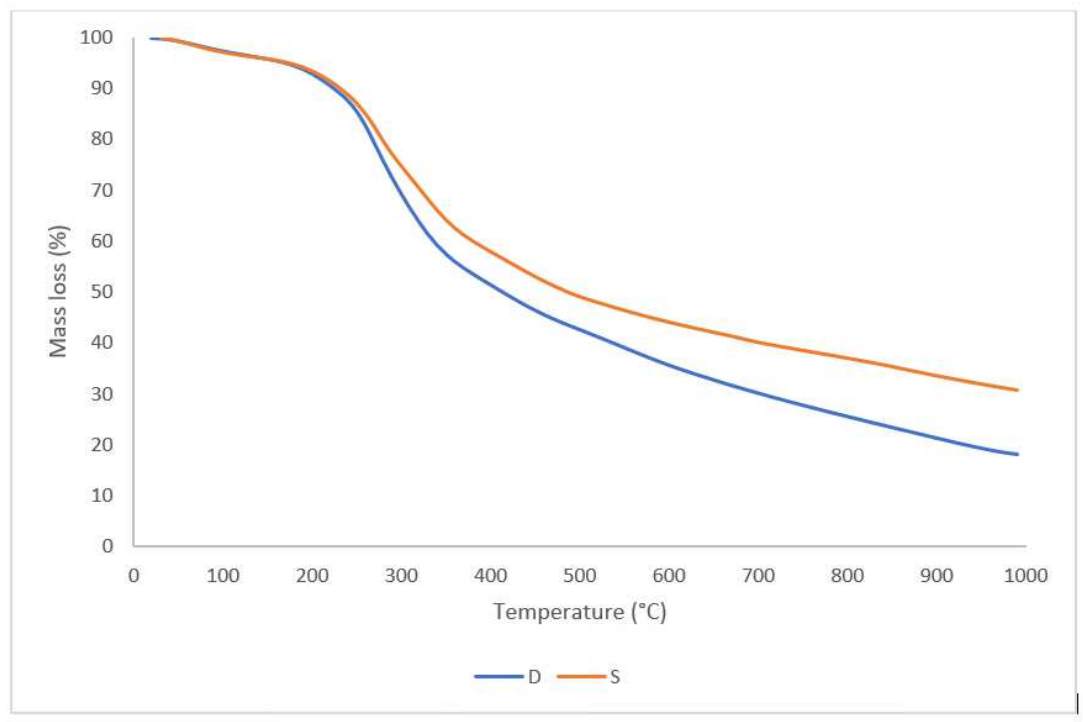

Fig. 1 Thermogravimetric curves of raw sewage sludge D \& S

Both samples D and S show heterogeneous morphology and composition as revealed by microscopic examination by SEM analysis in Figures 2 (a, b), (c, d), and EDS analysis in Figures 3 (a, b) and Figures 4 (a, b), respectively. The sponge-like morphology shown in Figure 2.b may be attributed to an organic water-repellent compound that adhered to the bubbles during the dissolved air flotation process. Both Figures 3 (a, b) and Figures 4 (a, b) reveal that the main elements in the sewage sludge samples were carbon and oxygen, with silica and aluminium at trace concentrations. In contrast to D sludge, energy dispersive X-Ray (EDX) examination of sample $\mathrm{S}$ revealed an advanced inorganic content, probably generated from domestic wastewater particles collected during decantation or solid-liquid separation. 

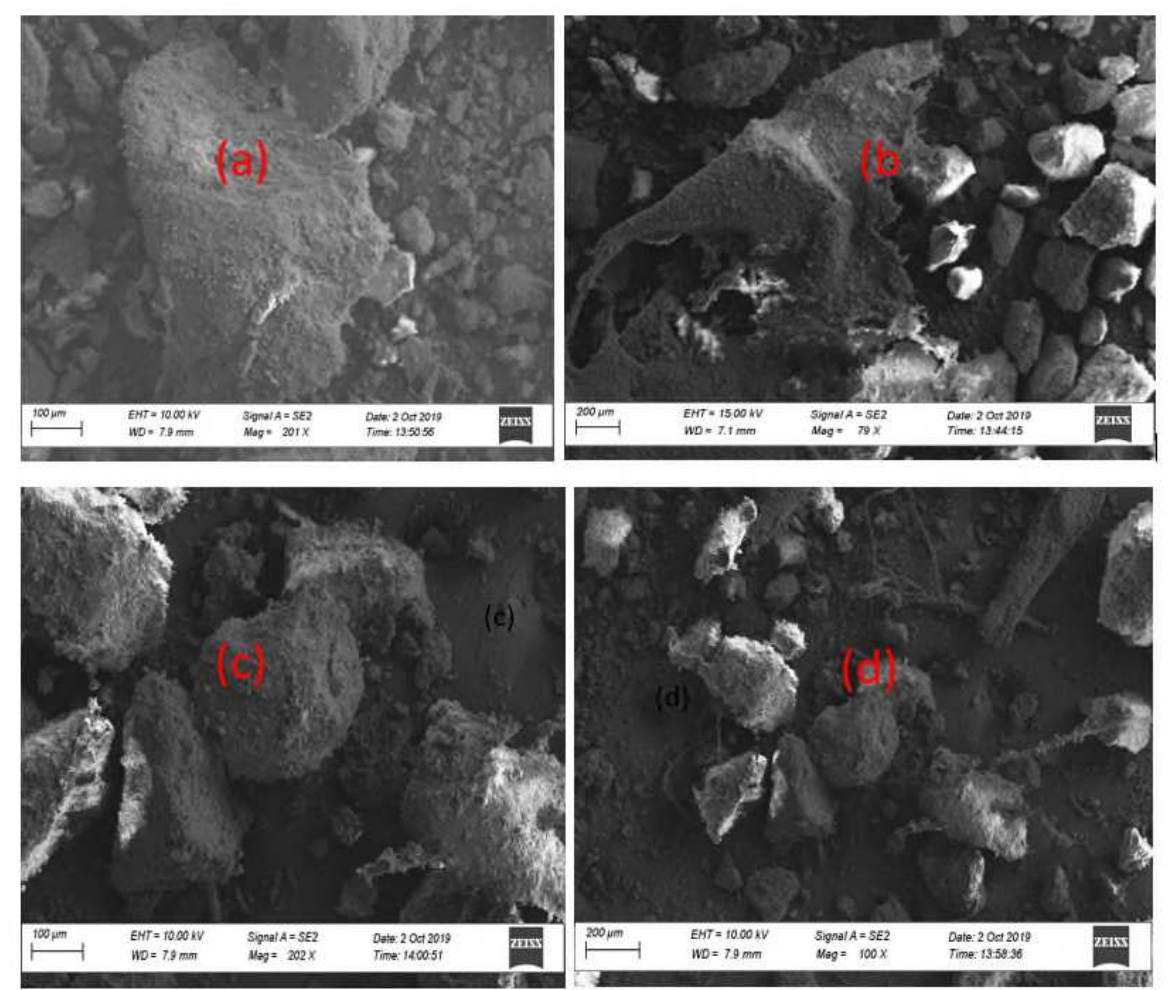

Fig. 2 microscopic observation of raw sewage sludge D: (a) and (b), S: (c) and (d).

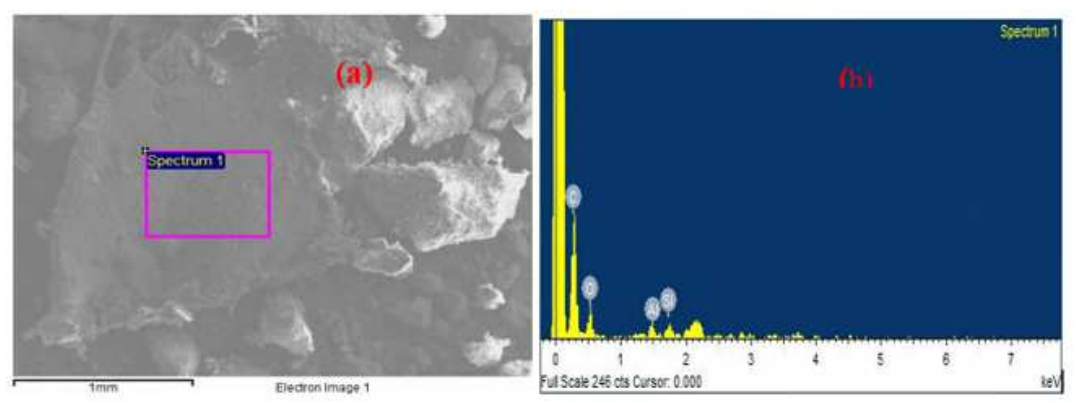

Fig. 3 Elemental analysis of raw sewage sludge D: (a) and (b 


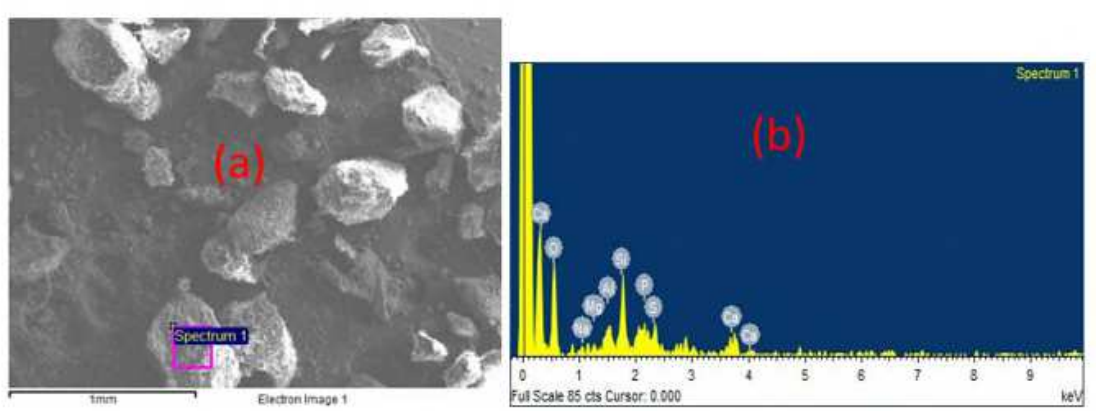

Fig. 4 Elemental EDS analysis of raw sewage sludge S: (a) and (b

Figure 5 shows the FT-IR spectra of the raw sewage sludge with wavenumbers ranging from $450 \mathrm{~cm}^{-1}$ to $4000 \mathrm{~cm}^{-1}$. Reading the peaks spectra wavelengths from left to right, the peak observed at $3688-3619 \mathrm{~cm}^{-1}$ is attributed to $\mathrm{OH}-\mathrm{kaolinite}$ and gibbsite lattice stretching [31,32], 2988-2901 $\mathrm{cm}^{-1}$ to -C-H group vibration [7,33], $1631 \mathrm{~cm}^{-1}$ and $1538 \mathrm{~cm}^{-1}$ to sulphur and nitrogen functional groups, respectively [33]. The shape of the shoulder peaks at $1050-1090 \mathrm{~cm}^{-1}$ was attributed to $\mathrm{Si}-\mathrm{C}$ or Si-O-Si bands (Liang et al., 2020), C-O-C vibration [33], and finally, under $1000 \mathrm{~cm}^{-1}$, the peaks at $749 \mathrm{~cm}^{-}$ 1, $535 \mathrm{~cm}^{-1}$, and $467 \mathrm{~cm}^{-1}$ were attributed to silica or calcium carbonate stretching [32,34]. Discard coal has a lower transmittance from $1498 \mathrm{~cm}^{-1}$ peaks than FT-IR spectra sludge. $1007 \mathrm{~cm}^{-1}, 1030 \mathrm{~cm}^{-1}$, implying that waste coal contains more mineral elements whereas sludge $\mathrm{S}$ has lower transmittance than $\mathrm{D}$, implying that the former contains more functional classes. 


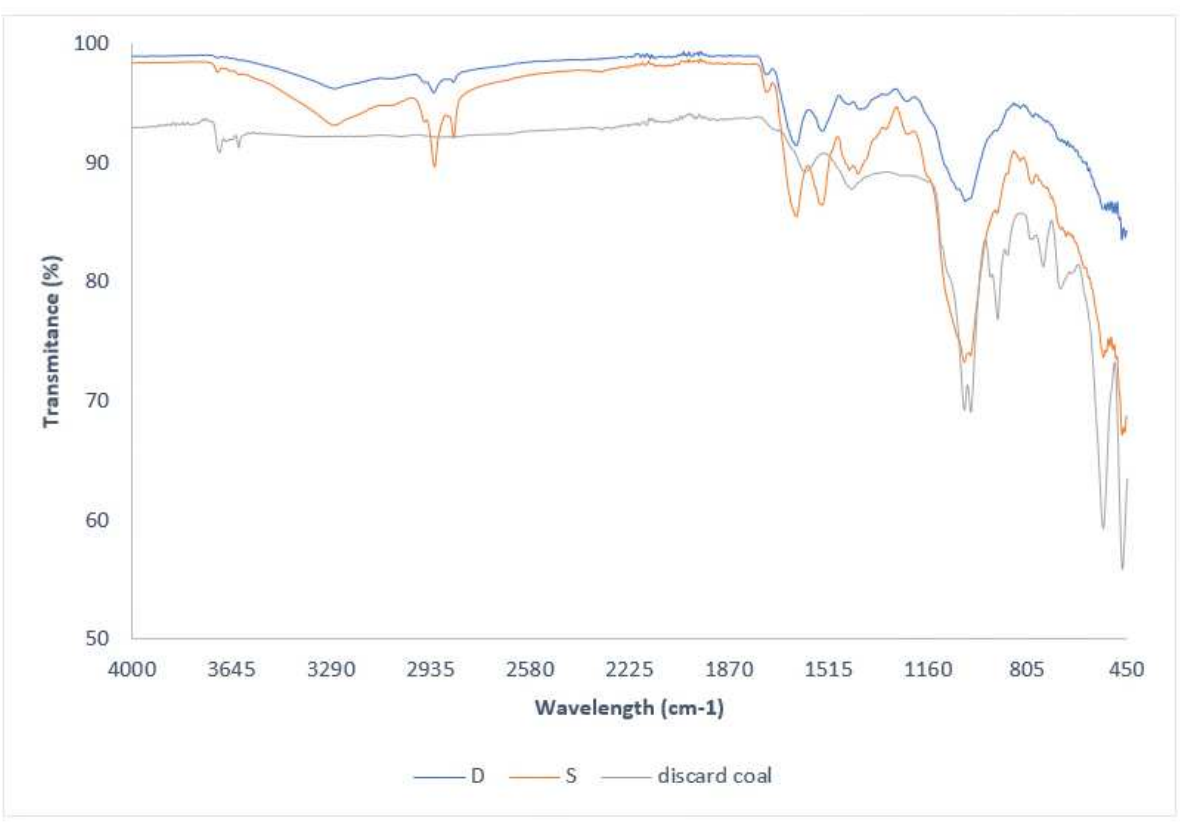

Fig. 5 FT-IR spectra for precursors D \&S

\subsection{Characterisation of activated samples}

Table 4 Nomenclature and conditions of the activation experiments

\begin{tabular}{|l|c|c|c|c|}
\hline Name & Sludge & discard coal & $\begin{array}{l}\text { Concentration } \\
\text { KOH: mol/l }\end{array}$ & Temperature $\left({ }^{\circ} \mathrm{C}\right)$ \\
\hline D-3-600 & D & No & 3 & 600 \\
\hline D-3-750 & D & No & 3 & 750 \\
\hline D-5-600 & D & No & 5 & 600 \\
\hline D-5-900 & D & No & 5 & 900 \\
\hline D-7-600 & D & No & 7 & 600 \\
\hline DC-3-900 & D & Yes & 3 & 900 \\
\hline DC-5-600 & D & Yes & 5 & 600 \\
\hline DC-5-750 & D & Yes & 5 & 750 \\
\hline DC-7-900 & D & Yes & 7 & 900 \\
\hline S-3-600 & S & No & 3 & 600 \\
\hline
\end{tabular}




\begin{tabular}{|l|l|l|l|l|}
\hline S-3-900 & S & No & 3 & 900 \\
\hline S-5-600 & S & No & 5 & 600 \\
\hline S-7-900 & S & No & 7 & 600 \\
\hline SC-3-600 & S & No & 3 & 900 \\
\hline SC-3-900 & S & Yes & 3 & 900 \\
\hline SC-5-900 & S & Yes & 5 & 900 \\
\hline SC-7-600 & S & Yes & 7 & 600 \\
\hline SC-7-750 & S & Yes & 7 & 750 \\
\hline
\end{tabular}

Figure 6.a shows the microscopic examination of the sorbent SC-3-600 after activation. Pyrolysis and washing stages may have facilitated cavity formation of highly formed cavities due to the remarkable depletion of inorganic and organic components [35]. Furthermore, some particles (Figure 6a and 6b) lack or have insignificant cavities, which may be attributable to a lack of volatile and decomposed matter escaping to facilitate porosity [9]. The EDS qualitative analysis (Figure 6.c) of the local particle (6.b) revealed inorganic characteristics as well as the presence of $\mathrm{K}$ and $\mathrm{Cl}$ from activation and washing, respectively. 

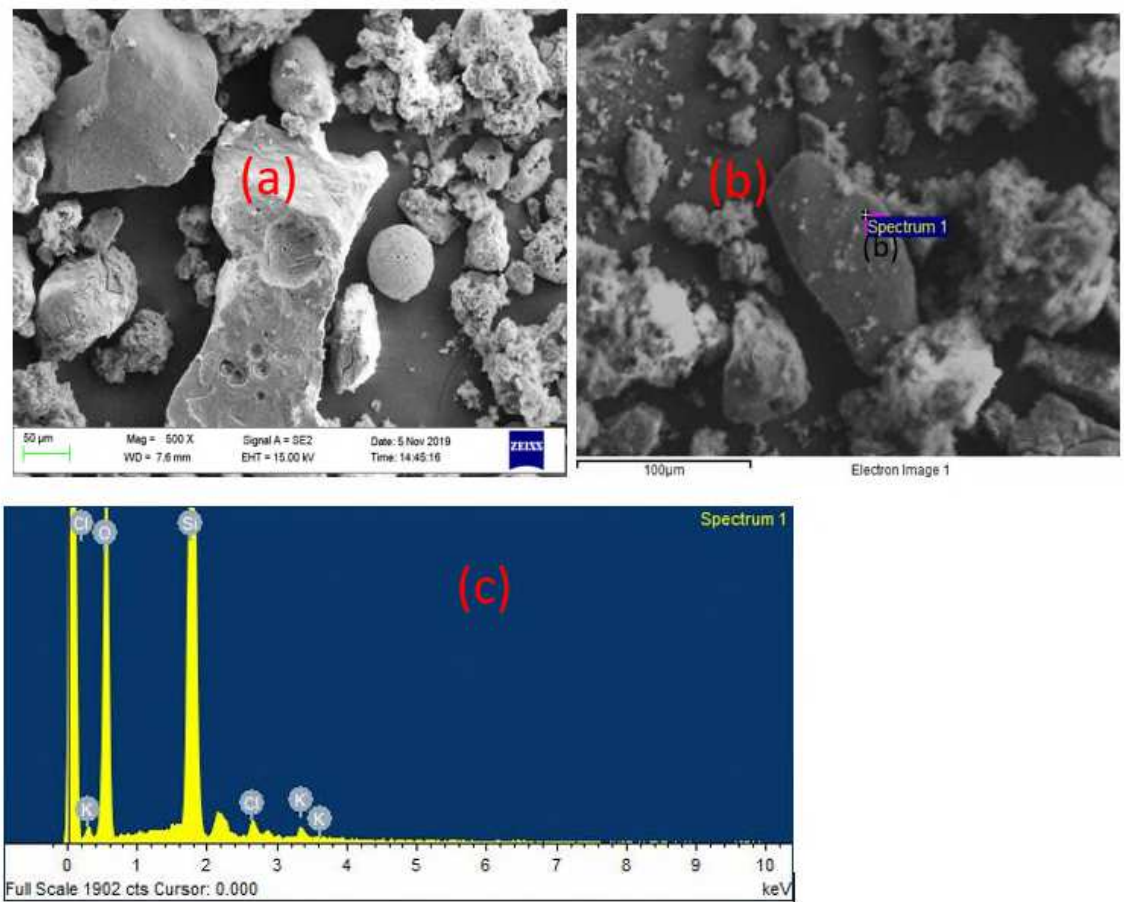

Fig. 6 SEM microscopic analysis of SBAC SC-3-600, (a) multiple particle (b) focus on particle without cavity after activation and (c) qualitative analysis of the targeted particle

The FT-IR spectrum of the various SBAC (as per Table 4) exhibited almost identical shape and peaks with different intensities regardless of the parameter involved in the synthesis process, as shown in Figures 7 and 8. The spectra have six main peaks, which are $3676 \mathrm{~cm}^{-1}, 2901-2998 \mathrm{~cm}^{-1}, 1394 \mathrm{~cm}^{-1}, 1225 \mathrm{~cm}^{-1}$, and $892 \mathrm{~cm}^{-1}$ in all SBAC samples.

In comparison to feedstock spectra, the disappearance of the wavelength peak at 470 $\mathrm{cm}^{-1}$ and $500 \mathrm{~cm}^{-1}$ in SBAC could be due to inorganic matter solubilisation during the acid washing phase $[36,37,38]$, while $798 \mathrm{~cm}^{-1}$ could be due to dehydrogenation reactions [24], $1631 \mathrm{~cm}^{-1}$ and $1538 \mathrm{~cm}^{-1}$ could be due to thermal degradation of protein for nitrogen related compound or sulphur [33]. 


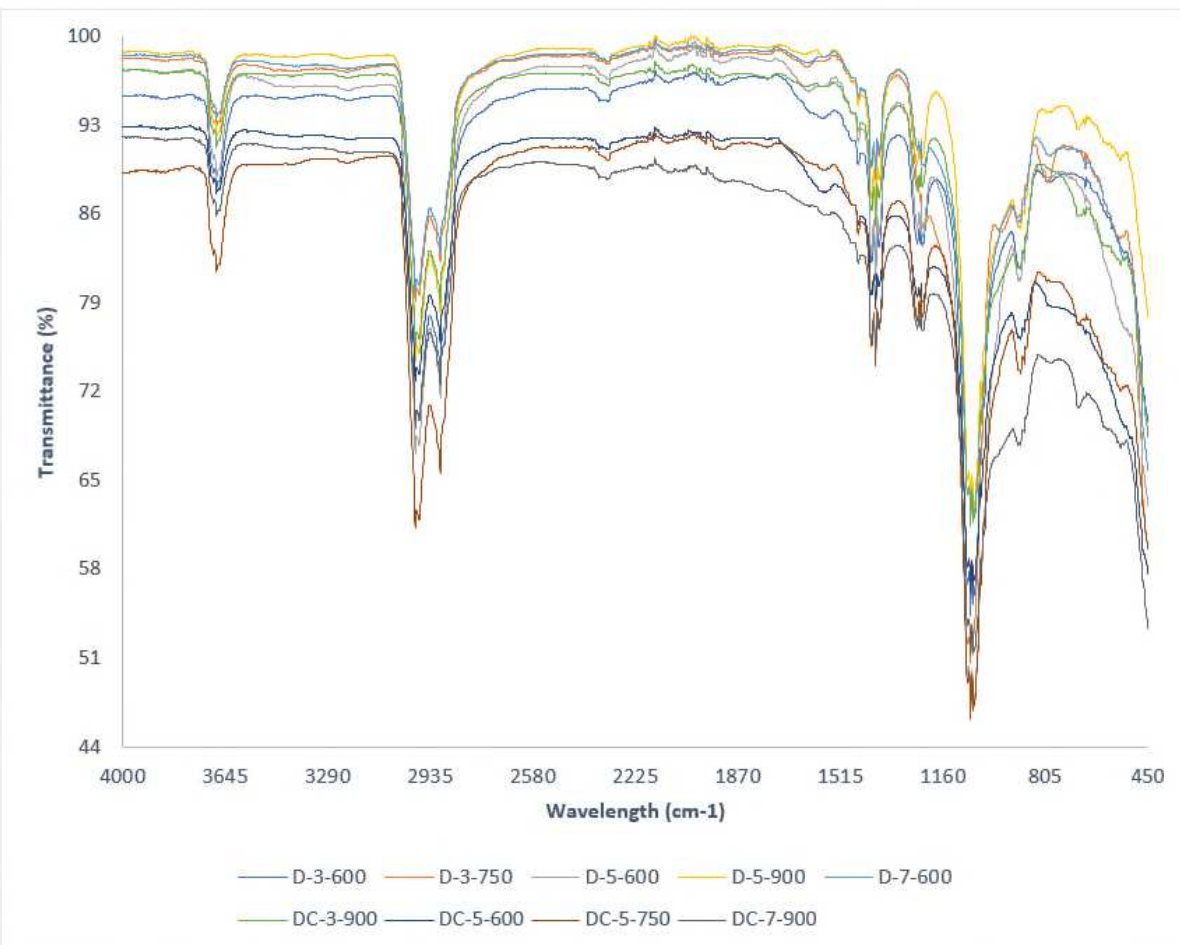

Fig.7 FT-IR spectra of SBAC obtained from raw sewage sludge D as precursor

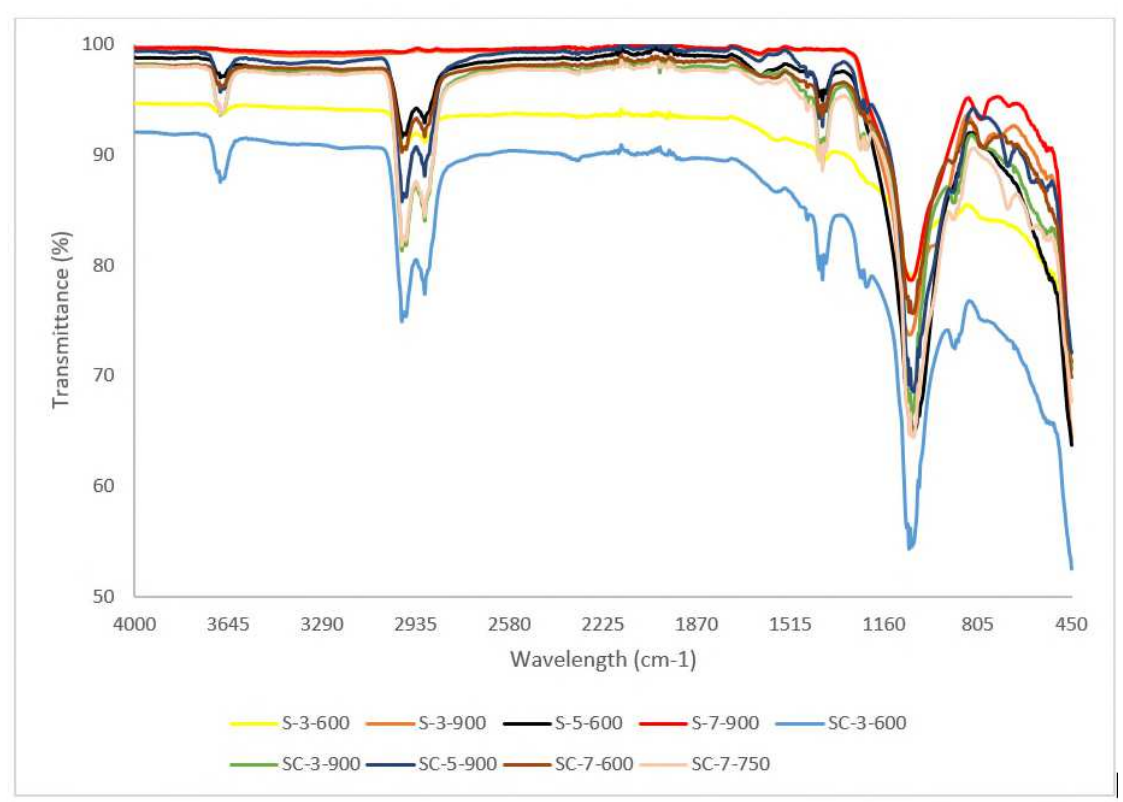


Fig.8 FT-IR spectra of SBAC obtained from raw sewage sludge S as precursor

280 The peaks associated with C-H group stretching not only shifted slightly from2859$2922 \mathrm{~cm}^{-1}$ in feedstock to a higher value $\left(2901-2988 \mathrm{~cm}^{-1}\right)$ in SBAC, which can be related to the presence of saturated group [11] but also transmittance increased after activation for all samples, which is in contrast to some literature $[7,33,39]$ in which it was argued that the disappearance of the peaks was due to the the decomposition of 285 fatty organic matter and dehydration [7]. Organometallic formation may be a possible explanation for the increased transmittance of SBAC pyrolyzed at lower temperatures followed by depletion as temperature rises; for example, the abundance of functional groups (hydroxyl, carboxyl) on the biochar surface synthesized from sewage sludge pyrolyzed at $300{ }^{\circ} \mathrm{C}$ reduced extractable cations due to the formation of organometallic 290 compounds $[40,41]$. The functional groups present in SBAC can be summarized as O$\mathrm{H}, \mathrm{C}=\mathrm{C}, \mathrm{C}=\mathrm{O}$, aliphatic C-H, Si-C, Si-O-Si, phosphate, and carbonate, based on the observations.

Com-AC has broad peaks $\left(2=25,3^{\circ}\right.$ and $\left.2=44,6^{\circ}\right)$ linked to its amorphous phases, while the XRD pattern (Figure 9a and b) demonstrated mineral phases transformation 295 from broad peak in the precursors to sharp in the manufactured absorbent, which clarified transition from amorphous to crystalline phase due to pyrolysis. XRD verified the existence of minerals such as wustite, quarts, illite, and feldspars in SBAC. It is 
worth noting that the presence of alkaline earth elements in the minerals (feldspars and illite) led to magnesium, calcium, and iron being classified as exchangeable cations.
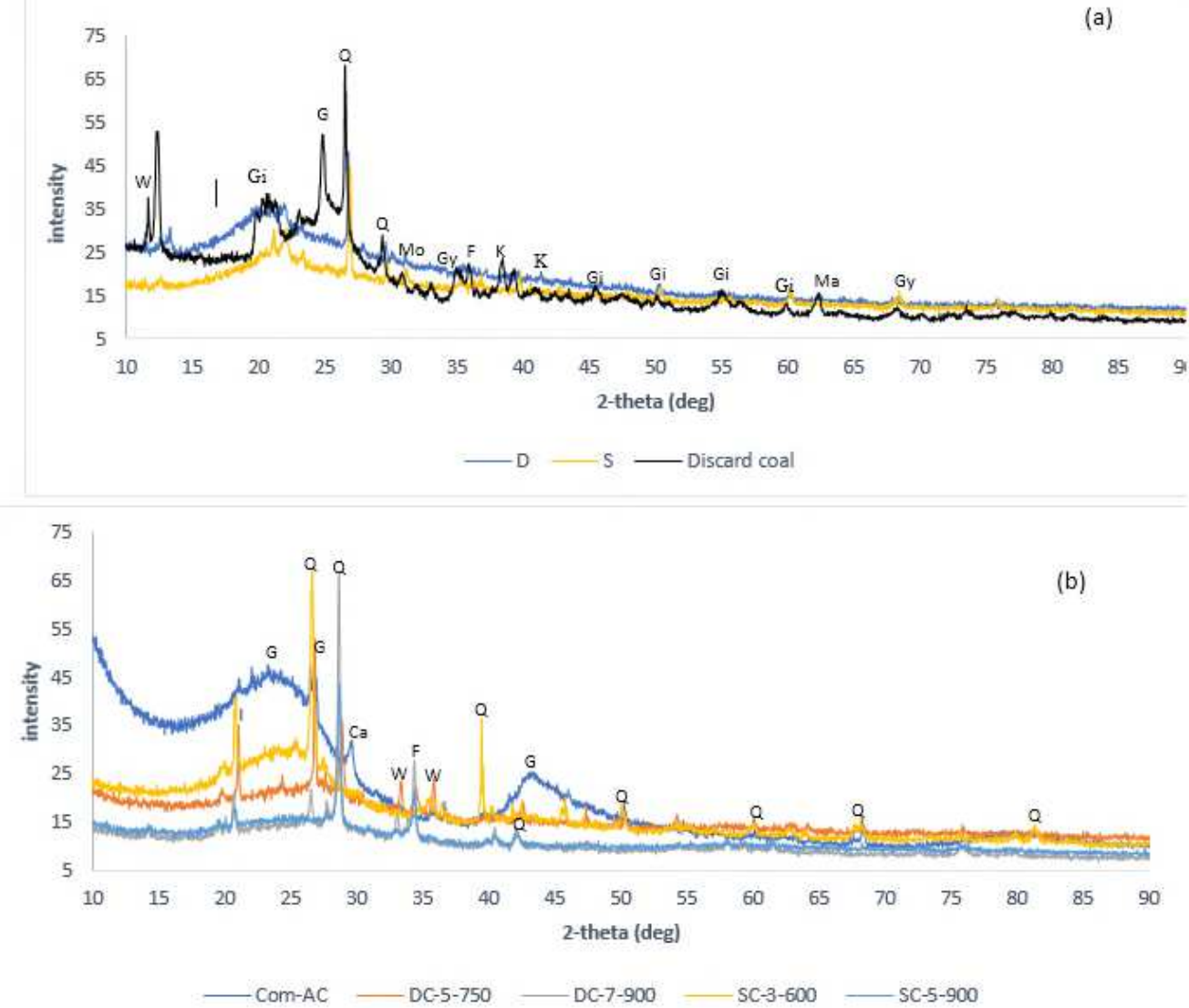

Ca: calcite , F: feldspar, G: graphite, Gi:gismondine, Gy:gypsum I:illite, K: kaolinite, Mo: modernite Q: quartz, W: wüstite,

Fig. 9 XRD graph of feedstock (a), SBAC and Com-AC (b) 


\subsection{Surface modification via oxidation}

The oxidation of SBAC resulted in surface functionalities modifications with formation of peaks in the oxidized adsorbent around 1550-1575 cm $\mathrm{cm}^{-1}$ (Fig. 10), which can be linked to symmetric $\mathrm{COO}^{-}$and nanoaromatic $\mathrm{C}=\mathrm{O}$ stretching entailed in formation of carboxylic functional groups (Teng et al., 2015) or $\mathrm{C}=\mathrm{C}$ bond of the aromatic skeleton ring of adsorbent [13]. On further notice the reduction in $-\mathrm{CH}\left(2901-2988 \mathrm{~cm}^{-1}\right)$ and $\mathrm{OH}\left(3640 \mathrm{~cm}^{-1}\right)$ stretching substances which may be ascribed to their solubility/affinity with $\mathrm{H}_{2} \mathrm{SO}_{4}$. On the other side, Com-AC did not have functional group.

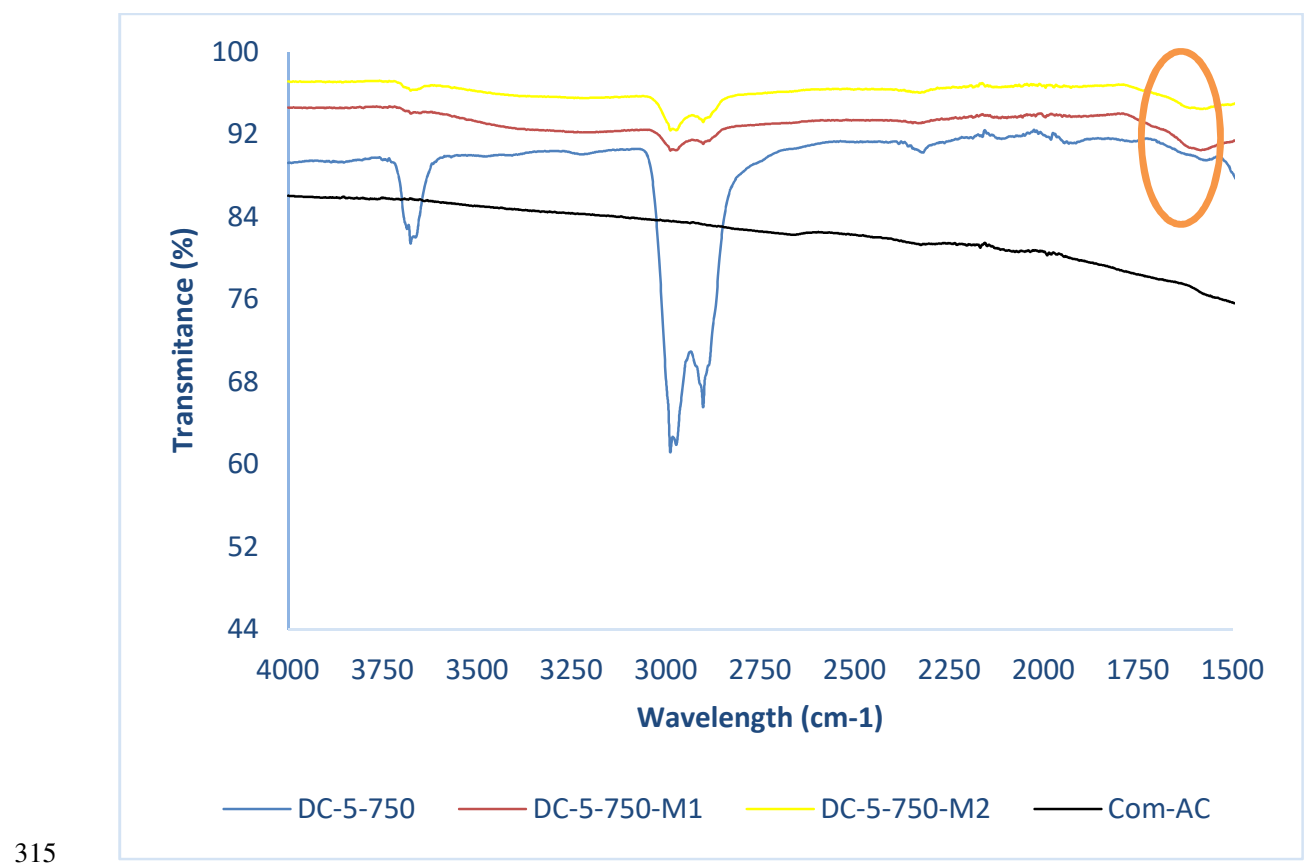

Fig. 10 FT-IR spectra of Com-AC, DC-5-750 and its two derived oxidized sorbents

Raman spectra pattern is shown in Figure 11, The peak located at $1587 \mathrm{~cm}^{-1}$ ( $\mathrm{G}$ band) and $1357 \mathrm{~cm}^{-1}$ (D band) are associated to $\mathrm{sp}^{2}$-bonded carbon and disorder of carbon structure respectively and their intensity $I_{G}$ and $I_{D}$ reveal the adsorbent degree of 
graphitization and carbon disorder structure from which $\mathrm{I}_{\mathrm{D}} / \mathrm{I}_{\mathrm{G}}$ ratio enunciates prevalence of carbon disorder structure over graphitization and vice-versa [13].

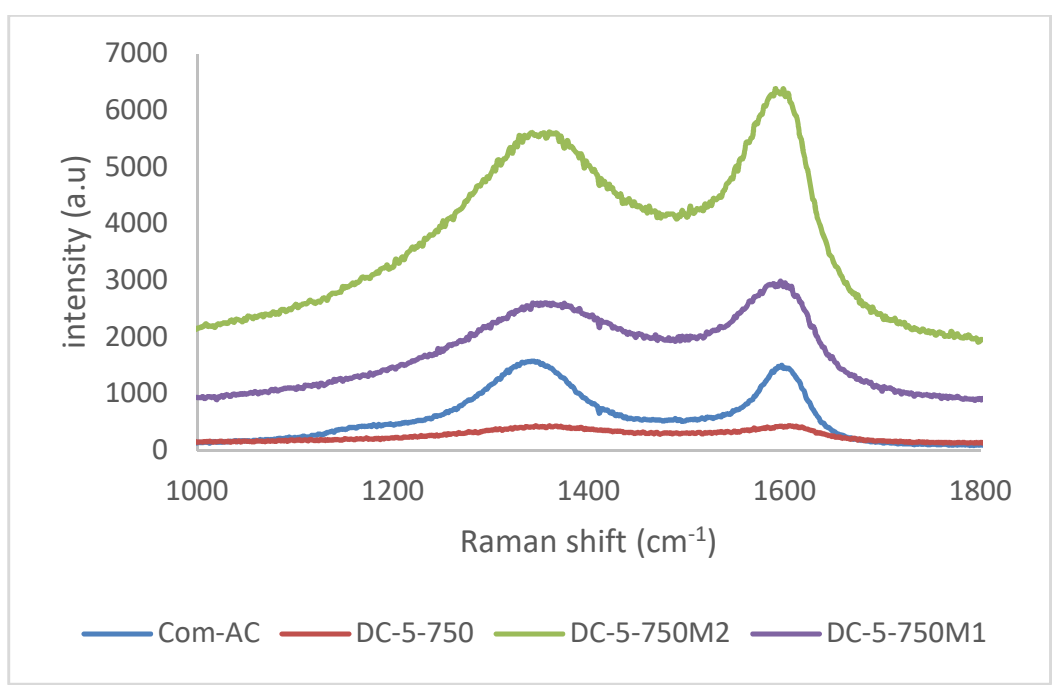

Fig. 11 Raman spectra of Com-AC, DC-5-750-oxidized adsorbents

As shown in Table 5, graphitic structure is more predominant than carbon disorder structure and augmented with oxidation, partial graphitization of activated carbon was reported with acidic oxidation treatment with $\mathrm{HNO}_{3}$ [42].

Table 5 intensity ratio of peak adsorbents

\begin{tabular}{llll}
\hline Adsorbents & $\mathbf{I}_{\mathbf{D}}\left(\mathbf{1 3 8 7} \mathbf{~ c m}^{\mathbf{- 1}}\right)$ & $\left.\mathbf{I}_{\mathbf{G}} \mathbf{( 1 5 8 7} \mathbf{c m}^{-\mathbf{1}}\right)$ & $\mathbf{I}_{\mathbf{D}} / \mathbf{I}_{\mathbf{G}}$ \\
\hline Com-AC & 1028,126 & 1397,75 & 0,735 \\
DC-5-750 & 385,270 & 398,887 & 0,965 \\
DC-55-750M1 & 2476,854 & 2921,75 & 0,847 \\
DC-5-750M2 & 5262,40 & 6284,252 & 0,837
\end{tabular}

The surface of oxidized adsorbent (Figure 12.b) exhibited less irregularities and soften surfaces than the unoxidized adsorbent (Figure 12.a) and Com-AC (Figure 12.c) probably as results of corrosive $\mathrm{H}_{2} \mathrm{SO}_{4}$-adsorbent surface interaction [18] and also disintegration of pore structure situated at the carbon edge [17]. XRD spectra of adsorbent are represented in Figure 13 after oxidation treatment the unoxidized sorbent exhibited a broader peak $\left(2 \theta=25,3^{\circ}\right)$ associated to amorphous or graphite structure as 
endorsed by Raman spectra analysis, on the other hand augmentation in peak $\left(2 \theta=30^{\circ}\right)$ ascribed to peak might be corollaries of other mineral (feldspar and illite) solubilisation/decline.

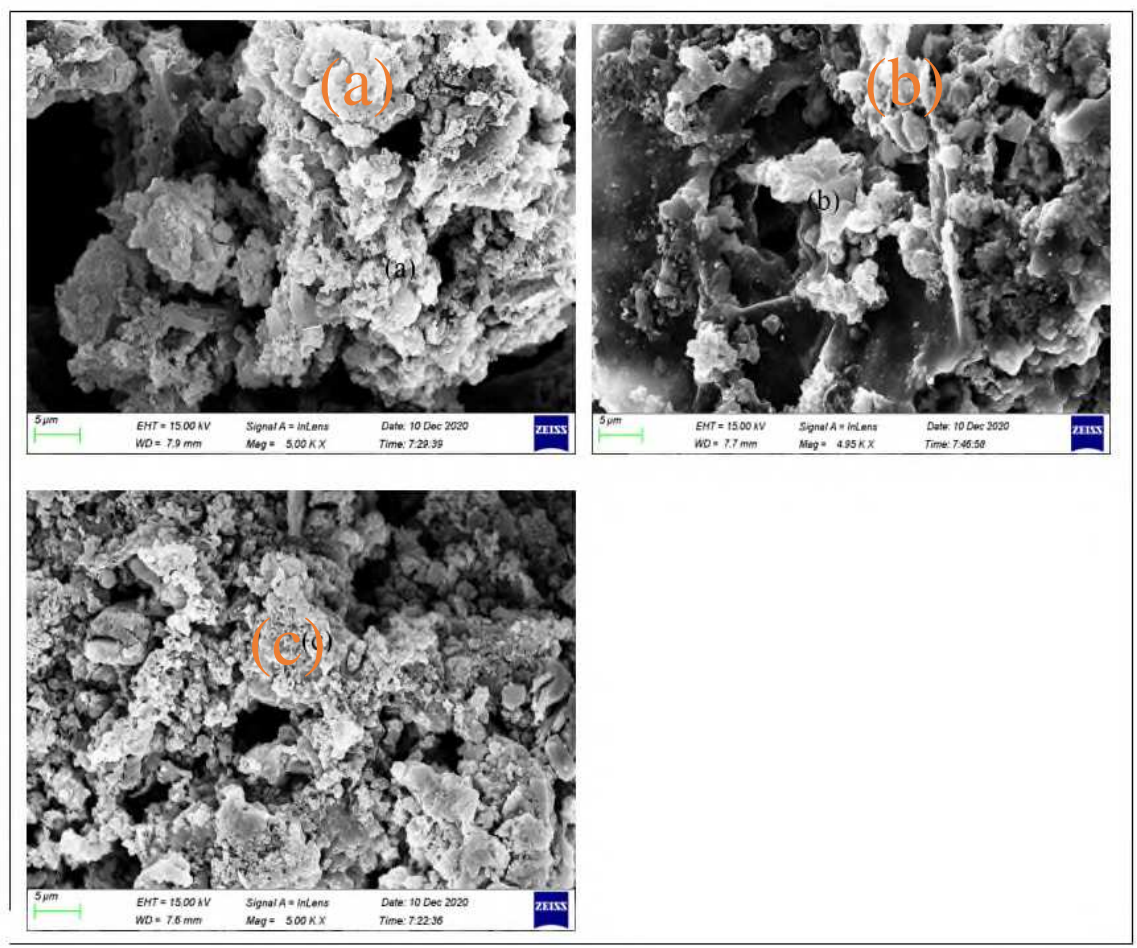

340

Fig. 12 morphology of (a) DC-5-750, (b) DC-5-750 M1 and (c) Com-AC 


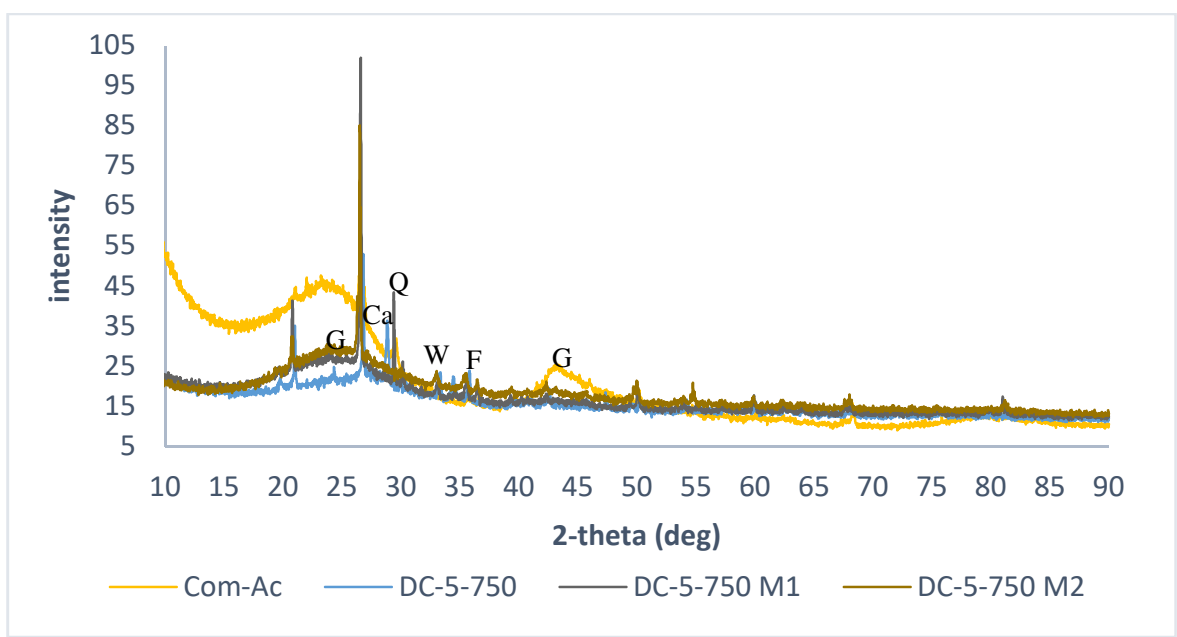

Fig. 13 XRD spectra of Com-AC, unoxidized (DC-5-750) and its oxidized sorbent

The oxidation with APS did not impact significantly carbon composition as per ultimate analysis results since the biggest difference was 6.771 \% (from DC-5-750: 23,612\% to DC-5-750M2:30,383\%) while with other sorbents (SC-3-600,SC-5-900,DC-7-900) variation was less than $2 \%$, alike tendency was reported by Ang et al. [22]

Furthermore, textural properties in Table 6 receded severely after modification, in case of bio-adsorbent derived from sludge S, for instance prior oxidation SC-3-600 had surface area of $281,72 \mathrm{~m}^{2} / \mathrm{g}$ that shrunk to $68,22 \mathrm{~m}^{2} / \mathrm{g}$ and $46,673 \mathrm{~m}^{2} / \mathrm{g}$ when treated with a solution of $1 \mathrm{M}$ and $2 \mathrm{M}$ APS respectively, probably due to thinness of walls pores, which are prone to collapse [43] and/or micropore occlusion [44]. In the case of DC-5-750, surface area varied slightly $\left(7,28-30,57 \mathrm{~m}^{2} / \mathrm{g}\right.$ : variation) and micropore areas changed from $124,14 \mathrm{~m}^{2} / \mathrm{g}$ to about $157,36 \mathrm{~m}^{2} / \mathrm{g}$ and $176,11 \mathrm{~m}^{2} / \mathrm{g}$ after modification with 1M APS and 2M APS respectively. After modifications DC-7-900 surface area $\left(247,57 \mathrm{~m}^{2} / \mathrm{g}\right)$ increased probably as results of micropore and mesopore collapse emerging from activated carbon surface etching by reagents, it was $285,59 \mathrm{~m}^{2} / \mathrm{g}$ for DC-7-900M1 and 295,31 m²/g for DC-7-900M2. 
Table 6 Structural properties and ultimate analysis results of SBAC after and before

\begin{tabular}{|c|c|c|c|c|c|c|c|c|c|}
\hline Adsorbent & $\begin{array}{l}\text { Modification } \\
\text { conditions }\end{array}$ & $\begin{array}{l}\mathrm{S}_{\mathrm{BET}} \\
\left(\mathrm{m}^{2} / \mathrm{g}\right)\end{array}$ & $\begin{array}{l}S_{\text {meso }} \\
\left(\mathrm{m}^{2} / \mathrm{g}\right)\end{array}$ & $\begin{array}{l}\mathrm{S}_{\text {micro }} \\
\left(\mathrm{m}^{2} / \mathrm{g}\right)\end{array}$ & $\begin{array}{l}\mathrm{V}_{\text {tot }} \\
\left(\mathrm{cm}^{3} / \mathrm{g}\right)\end{array}$ & $\begin{array}{l}V_{\text {micro }} \\
\left(\mathrm{cm}^{3} / \mathrm{g}\right)\end{array}$ & $\begin{array}{l}\text { Pore } \\
\text { size } \\
(\mathrm{nm}) \\
\end{array}$ & $\begin{array}{l}\mathrm{C} \\
(\%)\end{array}$ & $\begin{array}{l}\mathrm{H} \\
(\%)\end{array}$ \\
\hline Com-AC & - & 609,209 & 195,74 & 336,236 & 0,469 & 0,165 & 3,14 & 78,411 & 0,000 \\
\hline \multirow[t]{3}{*}{ SC-3-600 } & Unoxidized & 281,72 & 90,942 & 123,49 & 0,342 & 0,075 & 4,857 & 45,227 & 0,7411 \\
\hline & 1M APS & 68,227 & 24,098 & 35,241 & 0,0953 & 0,0175 & 5,58 & 47,411 & 1,007 \\
\hline & 2M APS & 46,573 & 19,631 & 14,807 & 0,085 & 0,0073 & 9,02 & 46,394 & 1,017 \\
\hline \multirow[t]{2}{*}{ SC-5-900 } & Unoxidized & 422,09 & 222,394 & 111.15 & 0,453 & 0,0495 & 4,296 & 2,014 & 0,000 \\
\hline & 2M APS & 313,05 & 61,156 & 223,75 & 0,291 & 0,117 & 3,604 & 1,891 & 0,000 \\
\hline \multirow[t]{3}{*}{ DC-5-750 } & Unoxidized & 312,79 & 100,212 & 124,14 & 0,366 & 0,0898 & 4,681 & 23,612 & 0,454 \\
\hline & 1M APS & 305.51 & 115,232 & 157.36 & 0,421 & 0,0741 & 4,51 & 29,901 & 1,087 \\
\hline & 2M APS & 282,22 & 77,816 & 176,113 & 0,299 & 0,083 & 4,244 & 30,383 & 1,019 \\
\hline \multirow[t]{3}{*}{ DC-7-900 } & Unoxidized & 247,57 & 129.83 & 175,60 & 0,265 & 0,0320 & 4,28 & 15,460 & 0,000 \\
\hline & 1M APS & 285,59 & 117,275 & 133,148 & 0,302 & 0,0666 & 4,099 & 14,831 & 0,0075 \\
\hline & 2M APS & 295,31 & 103,47 & 121,553 & 0,289 & 0,061 & 3,923 & 15,111 & 0,0079 \\
\hline
\end{tabular}

\subsection{Adsorption experiments}

To better understand kinetics order and intra particle diffusion, the effect of time was investigated using the following relationships:

$Q_{e}=\frac{\left(C_{0}-C_{e}\right) * V}{m}(1)$

$R p=\frac{\left(C_{0}-C_{e}\right)}{C_{0}} * 100(2)$

Where qe $(\mathrm{mg} / \mathrm{g}), \mathrm{C}_{0}(\mathrm{mg} / \mathrm{l}), \mathrm{C}_{\mathrm{e}}(\mathrm{mg} / \mathrm{l}), \mathrm{m}(\mathrm{mg})$ and $\mathrm{V}(\mathrm{ml})$ represent the adsorption capacity, initial concentration, equilibrium concentration, adsorbent mass and volume of liquid in contact with adsorbent respectively. The removal \%age is calculated via equation (2).

The first and second order kinetics models, as well as interparticle diffusion, are commonly used to understand the adsorption mechanism of pollutants with activated carbon [45].

Adsorption kinetics can be expressed in terms of the hypothesis that adsorbate removals obey a first-order kinetics:

$\frac{d q}{d t}=k_{1}\left(q_{e}-q_{t}\right)$ 
where qt and qe are the amount of pollutants adsorbed per mass of adsorbent $(\mathrm{mg} / \mathrm{g})$ at the targeted time and equilibrium, respectively, and $\mathrm{k}_{1}$ is the constant rate $\left(\mathrm{min}^{-1}\right)$.

After integration with conditions that $\mathrm{q}_{\mathrm{e}}=0$ if $\mathrm{t}=0$, equation (3) can be written:

$\ln \left(\frac{q_{e}-q_{t}}{q_{e}}\right)=-K_{1} t(4)$

Or alternatively

$\ln \left(1-\frac{q_{t}}{q e}\right)=\ln q_{e}-K_{1} t(5)$

The adsorption capacity at equilibrium (qe) and the first-order sorption rate constant $\left(\mathrm{k}_{1}\right)$ can be evaluated from the slope and the intercept respectively from plot of $\ln (1-$ qt/qe) vs t.

The second pseudo order kinetics is defined by equation:

$\frac{d q}{d t}=k_{2}\left(q_{e}-q_{t}\right)^{2}$

where $K_{2}$ is the second order rate constant, integration of equation (6) with initial conditions when $\mathrm{t}=0$ and $\mathrm{q}_{\mathrm{e}}=0$, lead to:

$395 \quad \frac{t}{q_{t}}=\frac{1}{K_{2} q_{e}^{2}}+\frac{t}{q_{e}}(7)$

$\mathrm{K}_{2}$ and qe can deducted from the slope and the intercept of the plot t/qt vs $t$, where qt is the adsorption capacity at a specific time.

The intraparticle diffusion model is a convenient means to depict diffusion mechanism and examine whether intraparticle diffusion is the rate-limiting step in the adsorption process. The intraparticle model diffusion is represented by:

$q_{t}=K_{\text {int }} t^{1 / 2}+C(8)$

Kint and $\mathrm{C}$ are determined from the slope and intercept of $\mathrm{qt} \mathrm{vs}^{1 / 2}$.

Where $\mathrm{K}_{\text {int }}$ is the intraparticle diffusion rate constant (mg. $\mathrm{g}^{-1} \mathrm{~min}^{-1 / 2}$ ) and $\mathrm{C}$ is the boundary layer effect intercept; the larger $\mathrm{C}$, the greater the contribution of surface sorption to the rate-controlling step.

The "preferred" oxidized and unoxidized SBAC were chosen based on removal evaluation tests performed at a constant temperature of $303 \mathrm{~K}$ for 180 and 360 min with an initial concentration of $50 \mathrm{mg} / \mathrm{l}$ of nitrate, $90 \mathrm{~min}$ and $180 \mathrm{~min}$ for MR with $75 \mathrm{ppm}$ as an initial concentration and an initial $\mathrm{pH}$ of 2 for nitrate and 4 for methyl red. The initial $\mathrm{pH}$ of 2 in the case of nitrate was chosen based on the hypothesis that adsorbent surfaces become positively charged as $\mathrm{pH}$ decreases, preventing competition with 
hydroxyl anions and $\mathrm{pH} 4$ in the case of methyl red to avoid competition with $\mathrm{H}^{+}$cations while attempting to keep the surface deprotonated (below the pHpzc for the oxidized adsorbent) as MR pKa = 5,1. Initially, unoxidized SBAC outperformed oxidized SBAC as shown in Figure 14, probably due to the former's proclivity for having a highly deprotonated surface at lower $\mathrm{pH}$. The adsorption capacity decreased as time progressed, with the exception of Com-AC, where it changed slightly from $16,32 \mathrm{mg} / \mathrm{g}$ to $13,2 \mathrm{mg} / \mathrm{g}$ for contact times of 180 and 360 minutes, respectively. Furthermore, SBAC (DC-5-750M1 and SC-5-900M2) released a significant amount of nitrate ion in solution after 360 minutes of agitation, while this amount was lower when the process was carried out with other adsorbents. This situation may be related to the release of compound contained in the adsorbent ash in the liquid phase and/or the adsorption equilibrium phenomenon, in which optimum equilibrium contact was reached. DC-5750 and SC-3-600, as well as the oxidized sorbents DC-5-750M2 and SC-3-600M2, were chosen for further nitrate adsorption experiments. The bio-adsorbent had mesopores, making it ideal for removing medium-sized substances from liquid process [1]. Despite having a larger surface area, SC-5-900 (422,09 m2/g) and SC-5-900M2 $(313,05 \mathrm{~m} 2 / \mathrm{g})$ had a lower adsorption capacity than other SBAC. This may be attributed to lower carbon content (Table 1) or the disappearance of acidic functional groups as temperatures rose [36], and this result confirmed the significance of functional group presence. Based on the test results in Figure 6, DC-5-750 M1 and DC-7-900 M1, with adsorption capacities of $127,634 \mathrm{mg} / \mathrm{g}$ and $124,376 \mathrm{mg} / \mathrm{g}$, respectively, were chosen for additional experiments in relation to Com-AC $(121,10 \mathrm{mg} / \mathrm{g})$ performances, as well as unoxidized SBAC (DC-5-750 and DC-7-900). Figure 7a depicts the nitrate removal pattern over time. Prior to 30 minutes of contact time, all adsorbents had negligible adsorption power, most likely due to film diffusion resistance (external diffusion) [46], but it increased significantly up to 120 minutes for Com-AC, DC-5-750, and DC-5$750 \mathrm{M} 1$ at $15,132 \mathrm{mg} / \mathrm{g}, 17,46 \mathrm{mg} / \mathrm{g}$, and $10,72 \mathrm{mg} / \mathrm{g}$, respectively. 


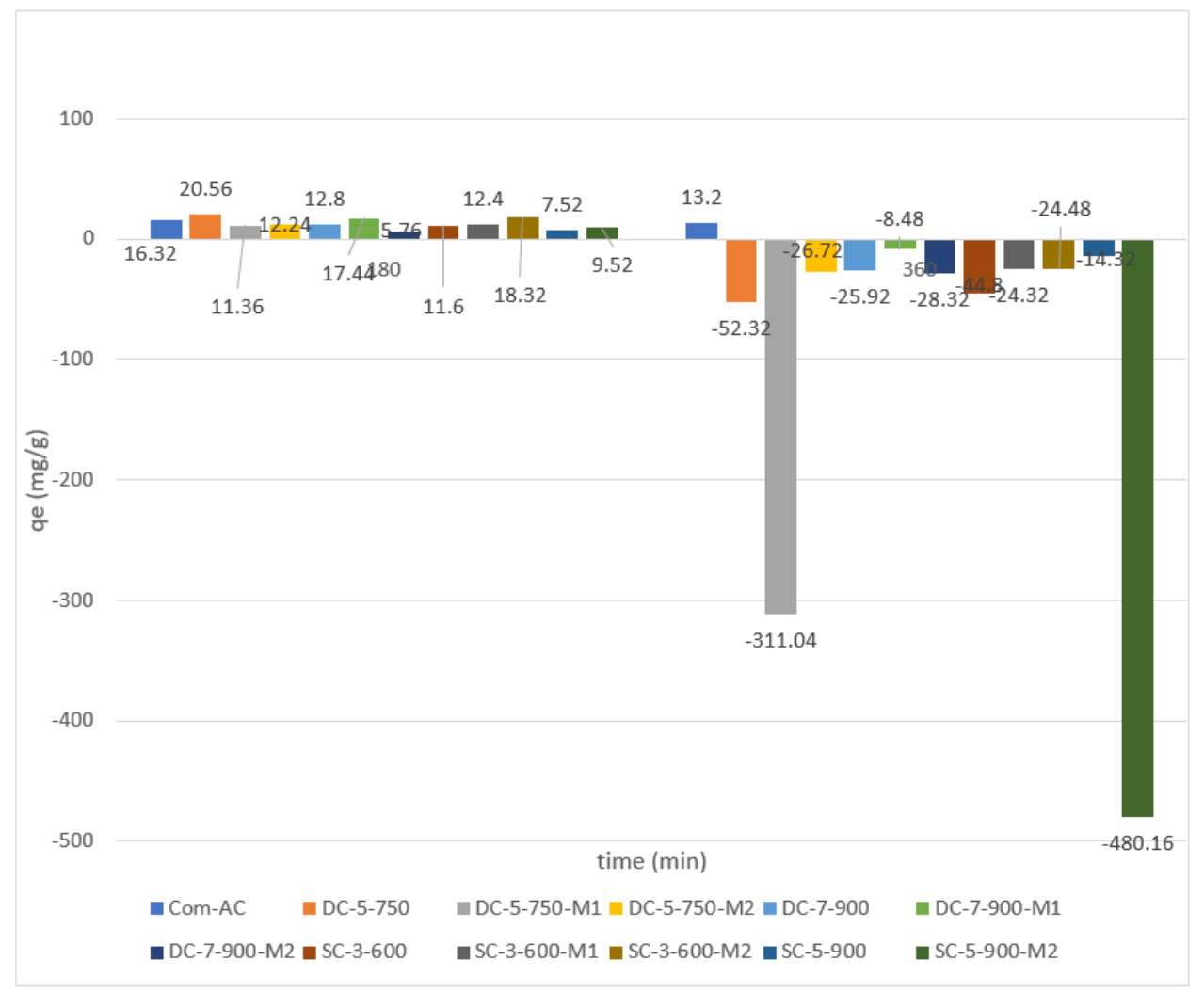

$440 \quad$ Fig. 14 preliminary adsorption capacity for nitrate

As illustrated in Figure 15, adsorption rises with time except for Com-AC, where the change was insignificant (from 123, $8 \mathrm{mg} / \mathrm{g}$ at $90 \mathrm{~min}$ to $121,2 \mathrm{mg} / \mathrm{g}$ at $180 \mathrm{~min}$ ), owing to the fact that equilibrium had already been established. Despite having the highest surface area, SC-5-900 and SC-5-900M2 had a lower qe than other sorbents, most likely due to a lower carbon content (Table 6) or a lack of acidic functional groups due to their depletion during temperature augmentation [14]. This finding emphasizes the critical nature of functional group presence.

As depicted in Figure 15, the synthesised sorbents with the highest adsorption potential were DC-5-750 M1 (127,6 mg/g) and DC-7-900 M1 (124,4 mg/g), and they were therefore chosen for future experiments, along with the unmodified sorbents (DC-5750 and DC-7-900). The upward tendency may be associated to pore diffusion and 
surface reaction which are deemed to present less component resistance than external diffusion [46], while stagnant trend after 120 min may be ascribed to occupation of available adsorption site by nitrate ions as the process progress [25,47,48], which weaken the interaction between sorbate and adsorbent surface [48].

Preliminary tests shown in Figure 6 revealed that the adsorption capacity increased significantly with time with a little fluctuation in Com-AC from $123,8 \mathrm{mg} / \mathrm{g}$ at 90 minutes to $121,172 \mathrm{mg} / \mathrm{g}$ at 180 minutes, implying that equilibrium had already been reached.

Although having a higher surface area, the adsorption capacity of SC-5-900 (422,1 $\mathrm{m} 2 / \mathrm{g})$ and SC-5-900M2 $\left(313,1 \mathrm{~m}^{2} / \mathrm{g}\right)$ was lower than other SBAC. This could be due to lower carbon content (Table 5) and/or depletion of acidic functional groups as they vanished with temperature rise (28). This observation further corroborated the importance of functional group presence.

Based on results in Figure 6, DC-5-750 M1 and DC-7-900 M1 with adsorption capacities of 127, $6 \mathrm{mg} / \mathrm{g}$ and 124, $4 \mathrm{mg} / \mathrm{g}$, respectively, were chosen for additional investigations in comparison to Com-Ac $(121,1 \mathrm{mg} / \mathrm{g})$ performances.

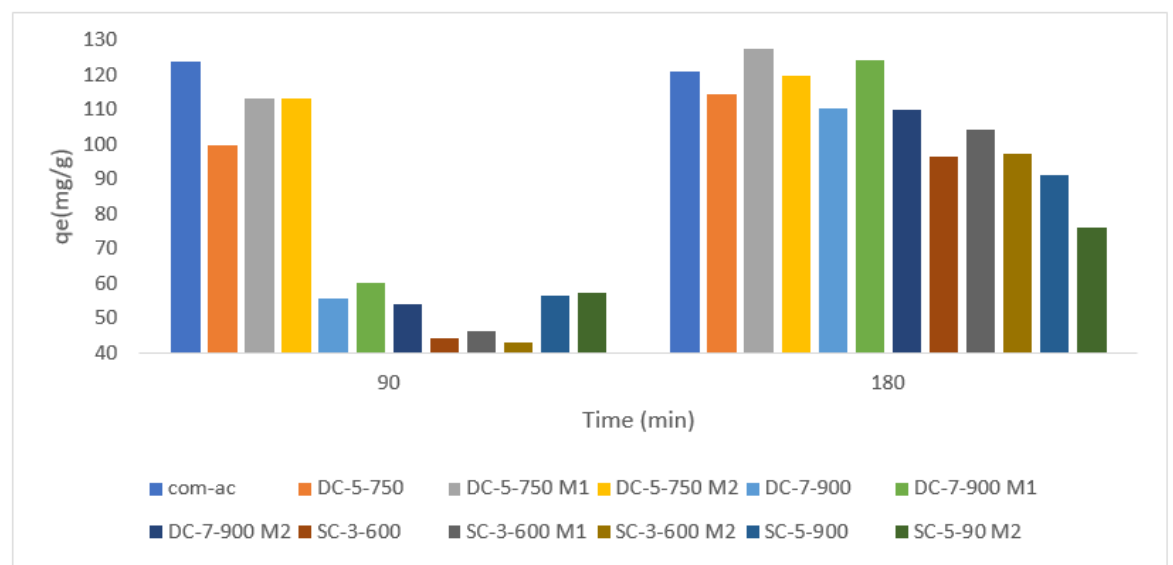

470

Fig. 15 preliminary adsorption capacity results for MR 

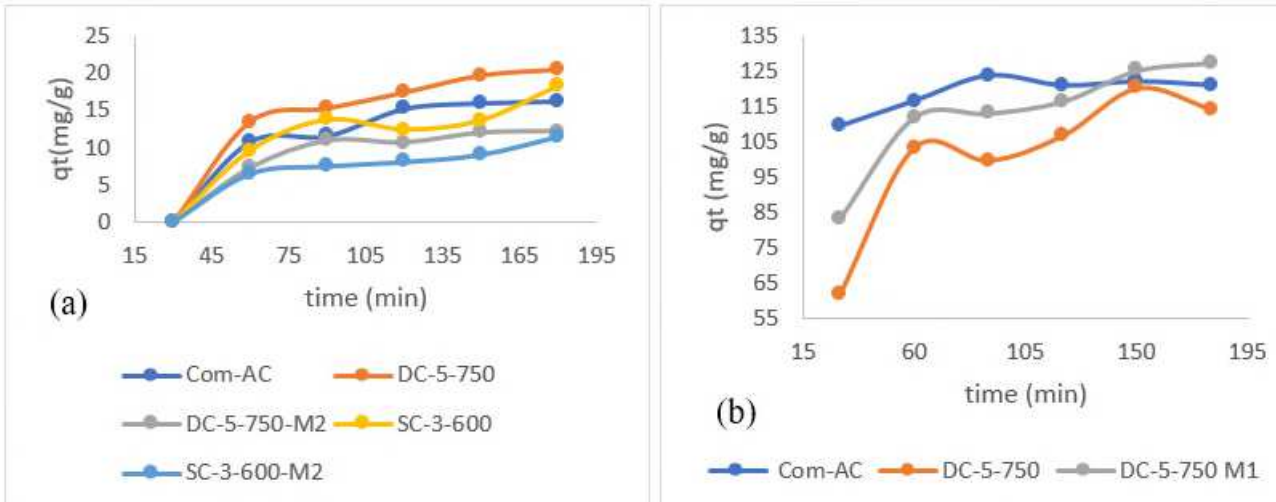

(b)

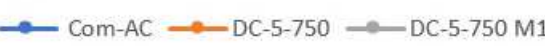

Fig. 16 effect of time on nitrate (a) and MR (b) adsorption capacity

Figure 16a depicts the nitrate removal trend as a function of time. Initially, all adsorbent adsorption capacities were negligible prior to 30 minutes of contact time possibly due to film diffusion resistance (external diffusion), and thereafter rose significantly for Com-AC (15,1 mg/g), DC-5-750 (17,5 mg/g), and DC-5-750M1 (10,72 mg/g).

Figure 16.b depicts the changes in dye adsorption capacity with contact time. Com-Ac adsorption capacities increased slightly from 109,63 mg/g at $30 \mathrm{~min}$ to $123,868 \mathrm{mg} / \mathrm{g}$ at $90 \mathrm{~min}$ and $121,107 \mathrm{mg} / \mathrm{g}$ at $180 \mathrm{~min}$, while DC-5-750 and DC-5-750M1 adsorption capacities increased from 83,08 mg/g and $113 \mathrm{mg} / \mathrm{g}$ at $30 \mathrm{~min}$ to $113,126 \mathrm{mg} / \mathrm{g}$ and $123,8 \mathrm{mg} / \mathrm{g}$ at $90 \mathrm{~min}$ and $114,36 \mathrm{mg} / \mathrm{g}$ and $127 \mathrm{mg} / \mathrm{g}$ at $180 \mathrm{~min}$.

The rapid increase in adsorption capability at the start of the process could be attributed to the abundance of adsorption sites [26,49].

Nitrate pseudo first order (PFO) and Pseudo second order (PSO) plots are recorded in Figure 17a-b and the corresponding parameters are recorded in Table 6. From the results in Figure $17 \mathrm{a}-\mathrm{b}$, Com-AC fitted better the PFO $\left(\mathrm{R}^{2}=0,9693\right)$ than PSO $\left(\mathrm{R}^{2}=0,8569\right)$ kinetic model, while other sorbents fitted better PSO kinetic model albeit lower coefficient correlation $\left(\mathrm{R}^{2}\right)$ 0,7859 and 0,793 for SC-3-600 and SC-3-600 M1 respectively. 


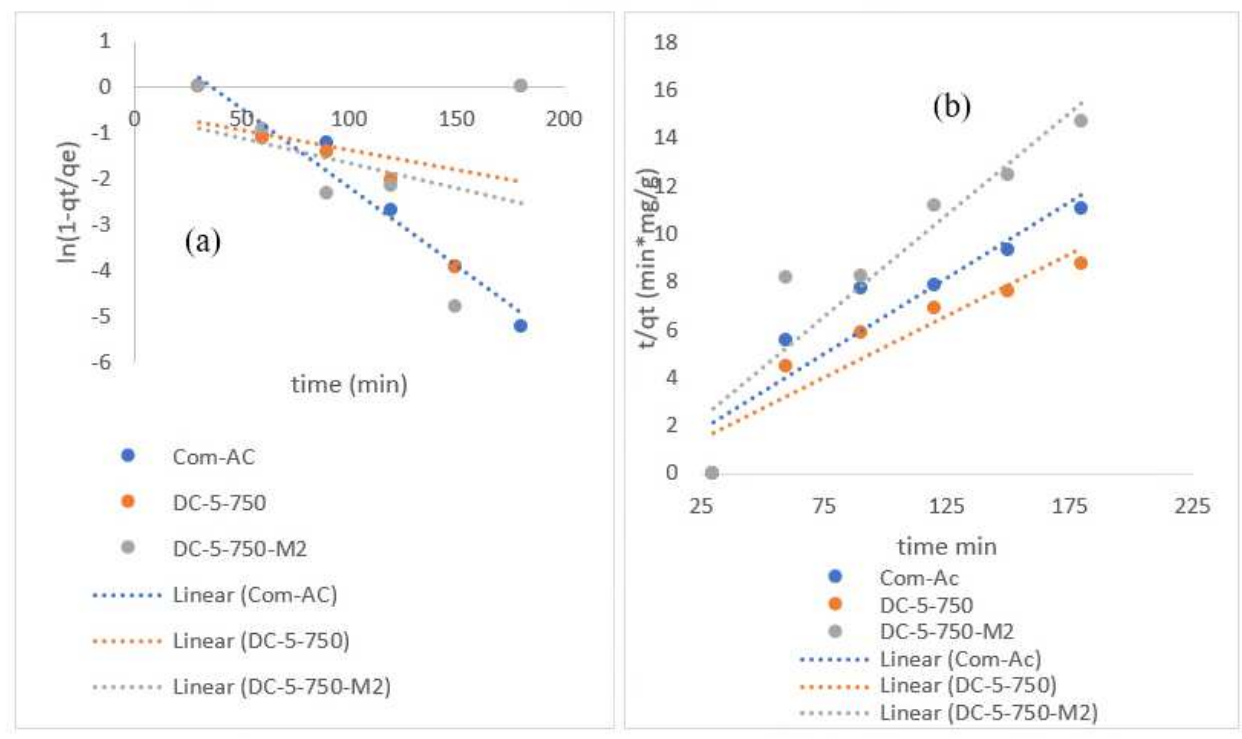

495

Fig. 17 nitrate PSO (a) and PFO (b) kinetic models plots.

Figure 18 depicts intraparticle diffusion model line plots for nitrate adsorption that did not pass through the axis origin, indicating that the nitrate removal mechanism was not solely controlled by the intraparticle diffusion model. Observations of similar nitrate removal were recorded by others $[25,50]$. 

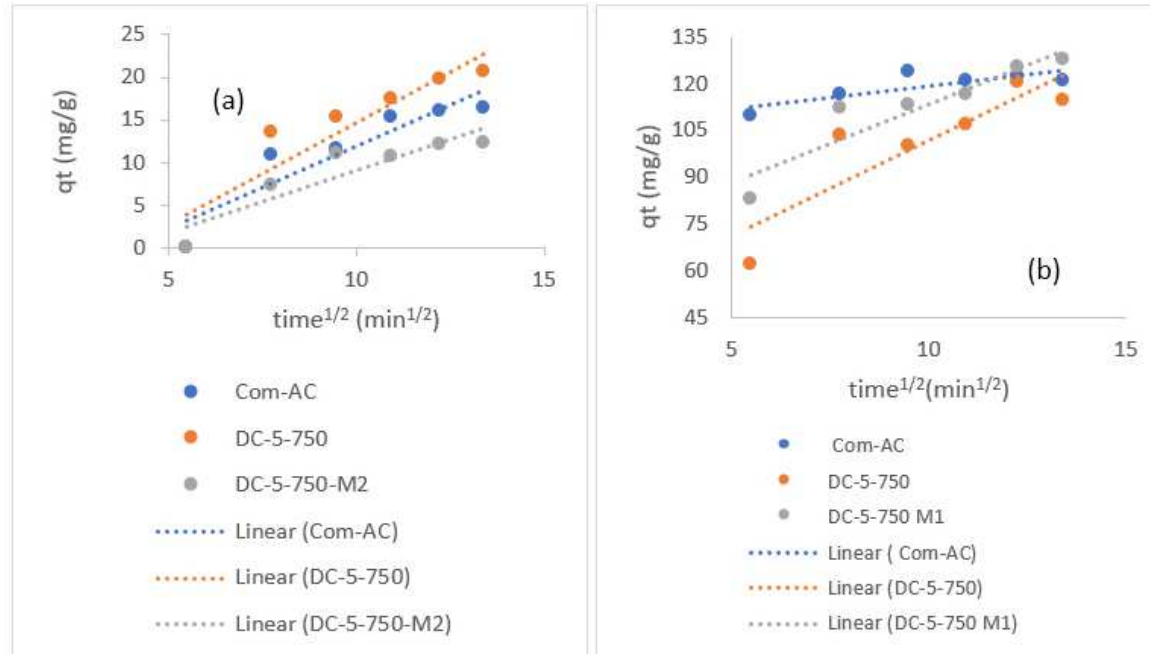

Fig. 18 intraparticle model diffusion of nitrate (a) and MR (b) adsorption

Table 7 parameters of PFO, PSO kinetics and intraparticle diffusion nitrate model

\begin{tabular}{|c|c|c|c|c|c|}
\hline & $\begin{array}{l}\text { Com- } \\
\mathrm{AC}\end{array}$ & DC-5-750 & $\begin{array}{l}\text { DC-5- } \\
750 \mathrm{M} 1\end{array}$ & $\begin{array}{l}\text { SC-3- } \\
600\end{array}$ & $\begin{array}{l}\text { SC-3- } \\
\text { 600M1 }\end{array}$ \\
\hline \multicolumn{6}{|l|}{ Pseudo first-order } \\
\hline Qe (mg/g) & 3,49 & N/A & N/A & N/A & N/A \\
\hline $\mathrm{K}_{1}\left(\min ^{-1}\right)$ & 0,0344 & N/A & N/A & N/A & N/A \\
\hline $\mathrm{R}^{2}$ & 0,9683 & 0,108 & 0,1128 & 0,1543 & 0,1186 \\
\hline \multicolumn{6}{|l|}{ Pseudo second order } \\
\hline Qe (mg/g) & 15,748 & 19,342 & 11,764 & 15,797 & 10,277 \\
\hline $\mathrm{K}_{2}\left(\mathrm{~g} \cdot \mathrm{mg}^{-1} \cdot \mathrm{min}^{-1}\right)$ & 0,016 & 0,016 & 0,037 & 0,0072 & 0,0091 \\
\hline $\mathrm{R}^{2}$ & 0,8569 & 0,8698 & 0,8663 & 0,7859 & 0,793 \\
\hline \multicolumn{6}{|c|}{ Interparticle diffusion } \\
\hline $\mathrm{K}_{\mathrm{id}}\left(\mathrm{g} \cdot \mathrm{mg}^{-1} \cdot \mathrm{min}^{-0,5}\right)$ & 2,327 & 2,367 & 1,451 & 1,937 & 1,2479 \\
\hline $\mathrm{C}$ & $-14,032$ & $-8,966$ & $-5,475$ & $-7,8526$ & $-5,159$ \\
\hline $\mathrm{R}^{2}$ & 0,8953 & 0,8525 & 0,8287 & 0,8446 & 0,8827 \\
\hline
\end{tabular}

Nitrate PFO and PSO parameters are shown in Table 7. It was noticed that Com-AC fitted better PFO $\left(\mathrm{R}^{2}=0,9693\right)$ than PSO $\left(\mathrm{R}^{2}=0,8569\right)$ kinetic model, whereas other sorbents fit better PSO kinetic model, albeit with lower coefficient correlation $\left(\mathrm{R}^{2}\right)$ 0,7859 and 0,793 for SC-3-600 and SC-3-600 M1, respectively. The plot of MR PFO and PSO kinetic models are depicted in Figures 19a and 19b.The MR adsorption 
process could not be depicted using the PFO kinetics model due to insufficient linearity fitting induced by the inherent equation formula where qe (adsorption capacity) is 515 concomitantly fitting data and determining value. The parameters for parameters value of MR PFO and PSO kinetic and intraparticle model are presented in Table 8.
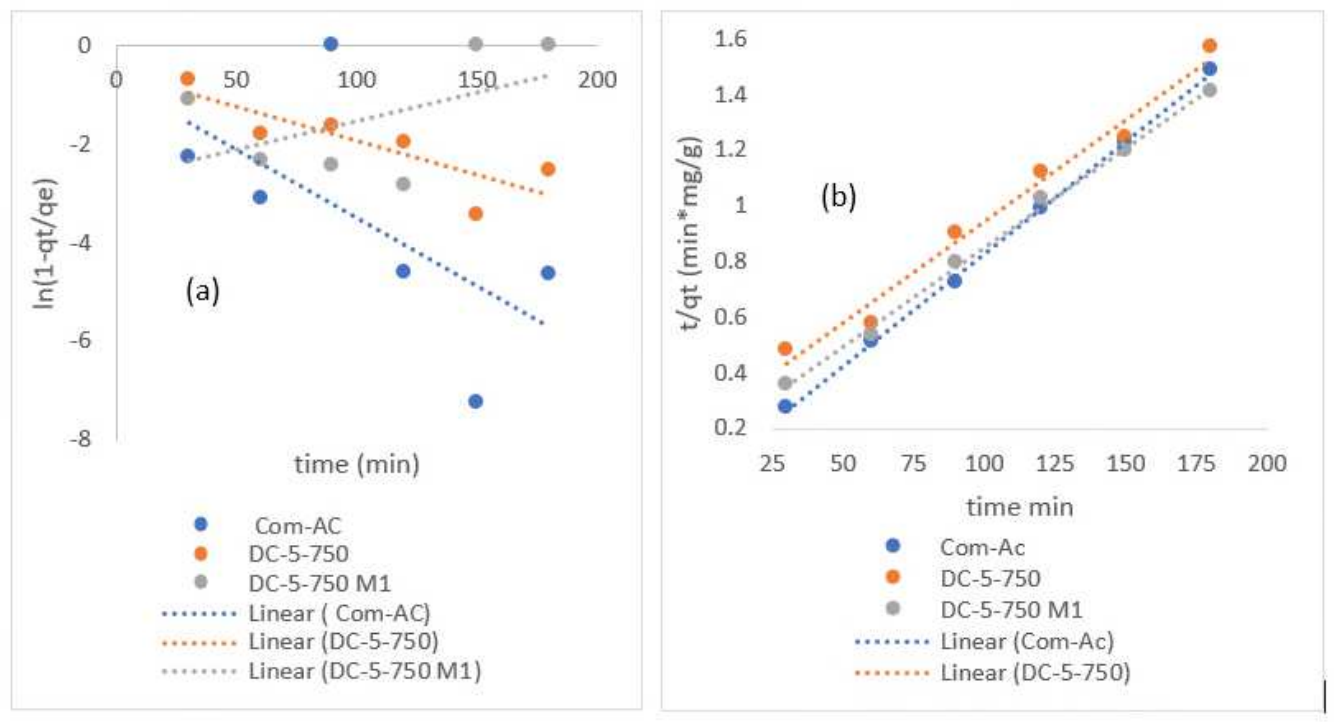

Fig. 19 MR PFO (a) and PSO (b) kinetic model 
Table 8 parameters value of MR PFO and PSO kinetic and intraparticle model

\begin{tabular}{|c|c|c|c|c|c|}
\hline & $\begin{array}{l}\text { Com- } \\
\mathrm{AC}\end{array}$ & $\begin{array}{l}\text { DC-5- } \\
750\end{array}$ & $\begin{array}{l}\text { DC-5- } \\
750 \mathrm{M} 1\end{array}$ & $\begin{array}{l}\text { DC-7- } \\
900\end{array}$ & $\begin{array}{l}\text { DC-7- } \\
900 \mathrm{M} 1\end{array}$ \\
\hline \multicolumn{6}{|l|}{ Pseudo first-order } \\
\hline $\mathrm{Qe}(\mathrm{mg} / \mathrm{g})$ & NA & NA & NA & NA & NA \\
\hline $\mathrm{K}_{1}\left(\mathrm{~min}^{-1}\right)$ & NA & NA & NA & NA & NA \\
\hline $\mathrm{R}^{2}$ & 0,3935 & 0,7036 & 0,2932 & 0,619 & 0,5439 \\
\hline \multicolumn{6}{|l|}{ Pseudo second order } \\
\hline$\overline{\mathrm{Qe}}(\mathrm{mg} / \mathrm{g})$ & 123,456 & 136,986 & 140,84 & 131,578 & 136,98 \\
\hline $\mathrm{K}_{2}\left(\mathrm{~g}^{*} \mathrm{mg}^{-1} * \mathrm{~min}^{-1}\right)$ & ${ }_{3}^{2,84} 10^{-}$ & ${ }_{4}^{2,441} 10^{-}$ & $3,55210^{-4}$ & ${ }_{4}, 82410^{-}$ & $2,16910^{-4}$ \\
\hline $\begin{array}{l}\mathrm{R}^{2} \\
\text { Interparticle diffusion }\end{array}$ & 0,9815 & 0,9815 & 0,9966 & 0,9831 & 0,9779 \\
\hline$\overline{\mathrm{K}_{\mathrm{id}}}$ & 1,4188 & 6,1545 & 5,045 & 6,165 & 5,802 \\
\hline $\mathrm{C}$ & 105,07 & 40,275 & 63,086 & 27,736 & 40,181 \\
\hline $\mathrm{R}^{2}$ & 0,643 & 0,7726 & 0,8644 & 0,978 & 0,9509 \\
\hline
\end{tabular}

The effect of $\mathrm{pH}$ was measured by varying the $\mathrm{pH}$ solution from 2 to 10 , as shown in Figure 20. The process was $\mathrm{pH}$ dependable, as evidenced by adsorption decrease with $\mathrm{pH}$ increasing, in the case of DC-5-750 (pHpzc=6,6) from 20,56 mg/g at pH 2, to 6,24 $\mathrm{mg} / \mathrm{g}$ at $\mathrm{pH} 6$ and 4,2 $\mathrm{mg} / \mathrm{g}$ at $\mathrm{pH} 10$, Com- $\mathrm{AC}(\mathrm{pHpzc}=10,3)$ and DC-5-750M2 $(\mathrm{pHpzc}=3,1)$. At $\mathrm{pH} 2$, adsorption potential was $16,32 \mathrm{mg} / \mathrm{g}$ and $12,24 \mathrm{mg} / \mathrm{g}$, respectively, at $\mathrm{pH} 6,11,12 \mathrm{mg} / \mathrm{g}$ and $9,6 \mathrm{mg} / \mathrm{g}$, respectively, and at $\mathrm{pH} 10,6 \mathrm{mg} / \mathrm{g}$ and $1,8 \mathrm{mg} / \mathrm{g}$. This pattern was more likely caused by: (i) favorable conditions of nitrate removal accentuated by electrostatic attraction as adsorbent surface bears positive charge at lower $\mathrm{pH}$. (ii) the presence of rivalry between nitrate ions and hydroxyl ions in basic solution, as also stated in other works using carbon-based activated carbon content $[47,48,51]$. In addition to the above-mentioned justifications, it may be further hypothesized that the underperformance of oxidized SBAC is due to the introduction of an acidic surface functional group; in the case of deprotonation, if $\mathrm{pH}>\mathrm{pHpzc}$, more binding sites for cationic sorbate are created on the surface than if it was an unoxidized adsorbent [44,52].

Taking into account that $\mathrm{MR}$ is negative if $\mathrm{pH}>\mathrm{pKa}$ and positive if $\mathrm{pHpKa}$ (Khan et al., 2018), the introduction of acidic functional groups caused a shift in $\mathrm{pHpzc}$, from neutral 6,6 (DC-5-750) to acidic after oxidation 3,1 (DC-5-750-M1) and Com-AC was basic 
10,2, surface functional group deprotonated when $\mathrm{pHpzc}<\mathrm{pH}$ and adsorbents surface becomes negatively charged [53]. In contrast to SBAC, Com-AC (pHpzc=10,2) has a wider range where the surface's net charge is positive. Adsorption of MR with changed SBAC, which had a lower pHpzc than unoxidized, was more $\mathrm{pH}$ dependable due to electrostatic attraction between the adsorbent negatively charge and positive MR below pH4 [26]; at pH4, the adsorption potential of DC5-750M1 and DC-7-900M1 was $127.634 \mathrm{mg} / \mathrm{g}$ and $117.176 \mathrm{mg} / \mathrm{g}$, respectively, from $\mathrm{pH} 6, \mathrm{pH} 8$, and $\mathrm{pH} 10$. Adsorption capacity decreased at $\mathrm{pH} 6$ from $97,488 \mathrm{mg} / \mathrm{g}$ for DC-5-750M1 and 109.278 for DC-7900M1 to $81.854 \mathrm{mg} / \mathrm{g}$ for DC-5-750M1 and 71,028 mg/g for DC-7-900M1, the results show that for the oxidized adsorbent at pH4 the adsorption mechanism was related to electrostatic attraction and hydrophobic associated to/or hydrogen bond [54]. Similarly, the adsorption potential of unoxidized SBAC (DC-5-750 and DC-7-900) decreased from $123,868 \mathrm{mg} / \mathrm{g}$ and $111,76 \mathrm{mg} / \mathrm{g}$ at $\mathrm{pH} 2$ to $81,854 \mathrm{mg} / \mathrm{g}$ and $90,32 \mathrm{mg} / \mathrm{g}$ at $\mathrm{pH} 10$.

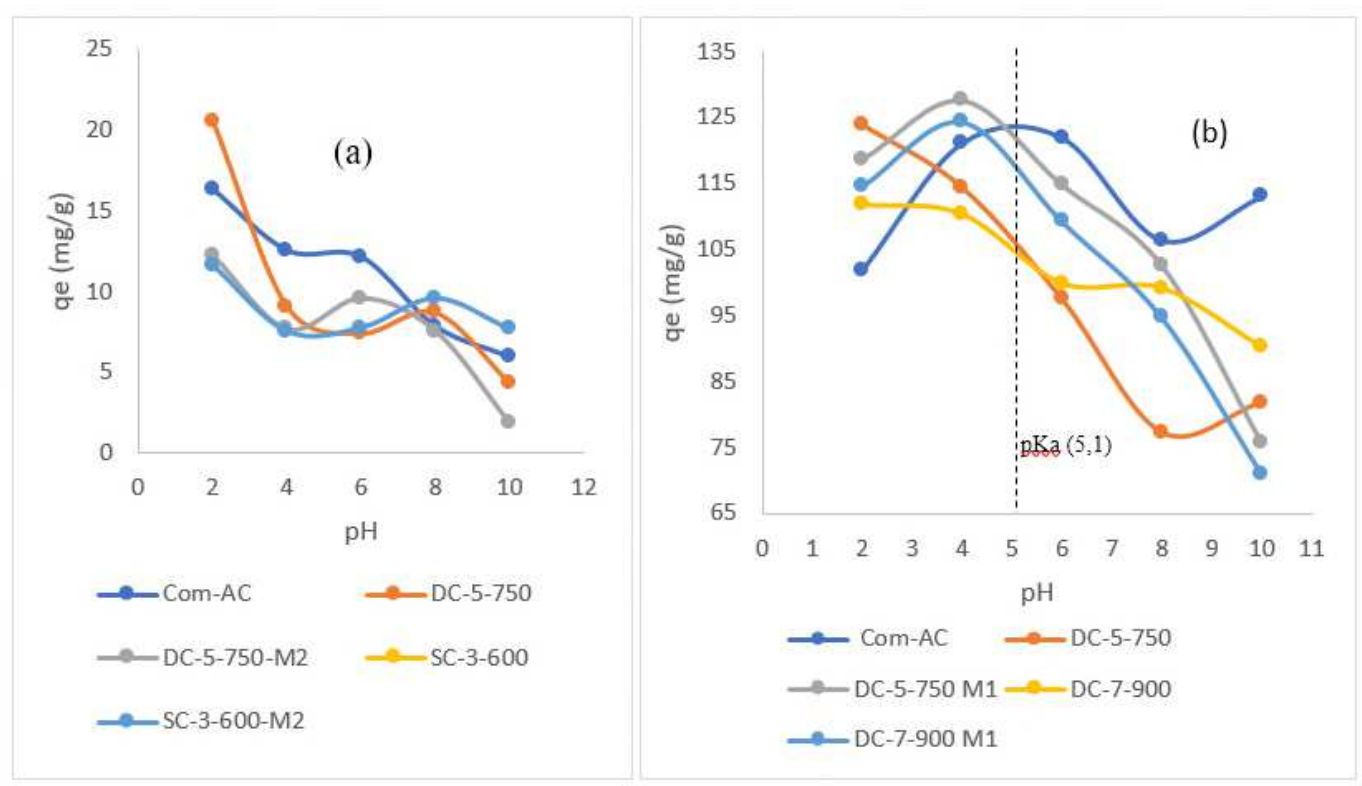

Fig. 20 Effect of pH solution on nitrate (a) and MR (b) adsorption 
The outperformance in basic solution could be attributed to adsorption site rivalry between hydroxyl ion and MR negatively charged ions [49]. Similarly, in an acidic solution with a $\mathrm{pH}$ of 2, the rivalry may have been between $\mathrm{H}^{+}$and positive MR [55] or/and repulsion force between protonated adsorbent surface and MR [26].

However, $\mathrm{pH}$ solution variation affected slightly the Com-AC adsorption capacity of MR, from $101.894 \mathrm{mg} / \mathrm{g}$ at $\mathrm{pH} 2$ to $113,04 \mathrm{mg} / \mathrm{g}$ at $\mathrm{pH} 10$, possibly because the electrostatic attraction mechanism was not very pronounced in the process because below pH 5,1 dye was charged positively and the protonated adsorbent had positive net charge, similar results were recorded on adsorption of cationic dye (Methyl blue) [56]. The adsorption capacity increased as initial concentration increased because driving force of concentration gradient prevailed and had propensity to subjugate mass transfer resistance barrier between solid and liquid interface. Conversely, the proportion of nitrate extracted decreased due to adsorbent site saturation, so a fraction of sorbate remained in solution [14]. As the initial pollutant concentration increased, the adsorbent's dye adsorption capacity increased, but the proportion of dye removed decreased due to a stronger driving force to overcome mass transfer resistance in terms of adsorption capacity and less available adsorption $[55,57]$ For example, the adsorption capacity of Com-AC, DC-5-750, DC-5-750M2, and SC-3-600 at the lowest initial concentration $(10 \mathrm{mg} / \mathrm{l})$ was $5,78 \mathrm{mg} / \mathrm{g}, 8,50 \mathrm{mg} / \mathrm{g}, 6,28 \mathrm{mg} / \mathrm{g}$, and $8,51 \mathrm{mg} / \mathrm{g}$, respectively; at $50 \mathrm{mg} / \mathrm{l}$ it was $16,32 \mathrm{mg} / \mathrm{g}, 20,56 \mathrm{mg} / \mathrm{g}, 12,24 \mathrm{mg} / \mathrm{g}$, and $18,32 \mathrm{mg} / \mathrm{g}$, respectively; and at the highest initial concentration $(90 \mathrm{mg} / 113 \mathrm{mg} / \mathrm{g}, 23,98 \mathrm{mg} / \mathrm{g}$, $14,65 \mathrm{mg} / \mathrm{g}$, and $18,778 \mathrm{mg} / \mathrm{g}$, while the proportion of nitrate extracted displayed the opposite pattern. At the lowest initial concentration (10 mg/l), it was 27,78 \%, 40,87\%, $30,19 \%$, and $40,91 \%$, and then decreased at the initial concentration of $50 \mathrm{mg} / \mathrm{l}$ to $16,32 \%, 20,56 \%, 12,4 \%$, and $18,32 \%$.

Figures 21 a-b and 22 a-b display Langmuir and Freundlich isotherms fitted to elucidate the nitrate and MR removal processes, respectively. Tables 9 and 10 provide data on the fitting parameters. For all adsorbents, the Langmuir isotherm suit the process better with a higher $R^{2}$ than the Freundlich model. The presence of $R_{L}$ values between 0 and 1 suggested that nitrate and MR adsorption were favorable on all sorbent surfaces (Tan and Hameed, 2017). It is worth noting, however, that as the $\mathrm{R}_{\mathrm{L}}$ value reached zero, $M R$ adsorption became more irreversible with increasing concentration $[12,35]$. 


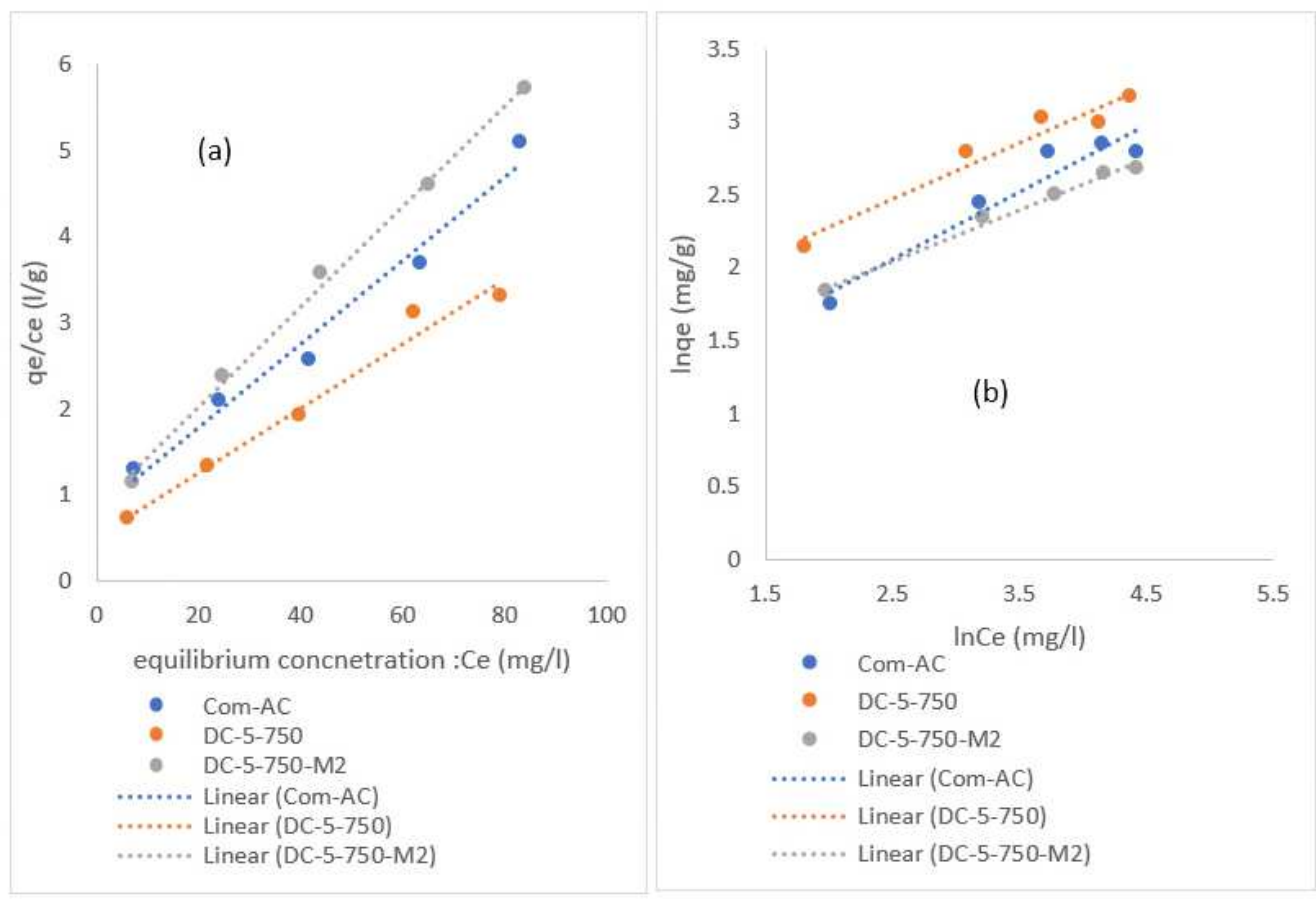

Fig. 21 Langmuir (a) and Freundlich (b) isotherm plot of MR adsorption 


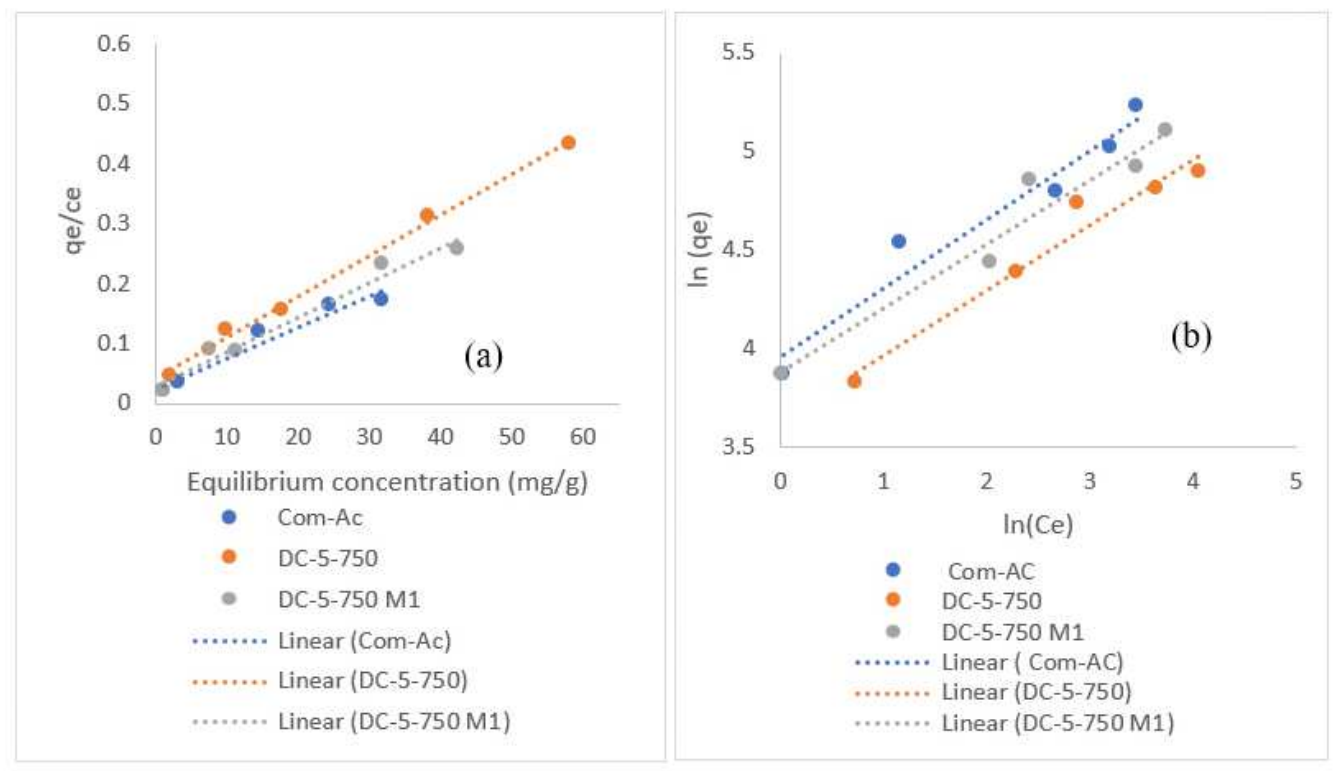

Fig. 22 Langmuir (a) and Freundlich (b) isotherm plot of nitrate adsorption

Table 9 parameters value of Langmuir and Freundlich isotherm of MR removal

\begin{tabular}{llllll}
\hline & Com-AC & DC-5-750 & $\begin{array}{l}\text { DC-5- } \\
750 \mathrm{M} 1\end{array}$ & DC-7-900 & DC-7-900M1 \\
\hline Langmuir & & & & & \\
Qm (mg/g) & 196,07 & 147,058 & 175,438 & 136,986 & 156,25 \\
$\mathrm{~K}_{\mathrm{L}}(\mathrm{L} / \mathrm{mg})$ & 0,2082 & 0,1645 & 0,1919 & 0,1648 & 0,2229 \\
$\mathrm{R}_{\mathrm{L}}$ & $0,1617-0,037$ & $0,194-0,046$ & $0,1724-0,04$ & $0,1953-0,0463$ & $0,1521-0,0346$ \\
$\mathrm{R}^{2}$ & 0,9515 & 0,9955 & 0,9707 & 0,9992 & 0,9967 \\
Freundlich & & & & & \\
$\mathrm{K}_{\mathrm{F}}(\mathrm{mg} / \mathrm{g})(1 / \mathrm{mg})^{1 / \mathrm{n}}$ & 51,997 & 37,765 & 48,443 & 33,794 & 45,141 \\
$1 / \mathrm{n}(\mathrm{l} / \mathrm{mg})$ & 0,035 & 0,3306 & 0,324 & 0,345 & 0.3199 \\
$\mathrm{R}^{2}$ & 0,9492 & 0,957 & 0,9463 & 0,9242 & 0,9578 \\
\hline
\end{tabular}


Table 10 comparison of MR adsorption capacity with literature values

605

\begin{tabular}{|c|c|c|c|c|c|}
\hline $\begin{array}{l}\text { Adsorbent } \\
\text { type }\end{array}$ & $\begin{array}{l}\text { Surface } \\
\text { area } \\
\left(\mathrm{m}^{2} / \mathrm{g}\right)\end{array}$ & $\begin{array}{l}\text { Solution } \\
\mathrm{pH}\end{array}$ & $\begin{array}{l}\text { Concentration } \\
\text { range }\end{array}$ & $\mathrm{q}_{\mathrm{m}(\mathrm{mg} / \mathrm{g})}$ & Reference \\
\hline $\begin{array}{c}\mathrm{NaOH} \\
\text { lemongrass } \\
\text { leaves } \mathrm{AC}^{*}\end{array}$ & 834,04 & 2 & $25-500$ & 76,923 & [6] \\
\hline $\begin{array}{c}\mathrm{KOH} \\
\text { durian seed } \\
\mathrm{AC}\end{array}$ & 980,62 & - & $25-500$ & 384,62 & [49] \\
\hline $\begin{array}{c}\text { Iron } \\
\text { oxidized AC }\end{array}$ & 153,32 & - & - & 526 & {$[26,58]$} \\
\hline $\begin{array}{c}\mathrm{K}_{2} \mathrm{CO}_{3} \\
\text { custard apple } \\
\mathrm{AC}\end{array}$ & 431,05 & 5 & $80-120$ & 171,23 & \\
\hline $\begin{array}{c}\mathrm{H}_{3} \mathrm{PO}_{4} \\
\text { custard apple } \\
\mathrm{AC}\end{array}$ & 1065 & 4 & $80-120$ & 435,25 & \\
\hline $\begin{array}{l}\text { Woody } \\
\text { biochar }\end{array}$ & 4,96 & - & - & 156,25 & [30] \\
\hline COM-AC & 630,209 & 4 & $25-125$ & 196,07 & This \\
\hline DC-5-750 & 312,79 & 4 & $25-125$ & 147,058 & work \\
\hline $\begin{array}{l}\text { DC-5- } \\
750 \mathrm{M} 1\end{array}$ & 305,51 & 4 & $25-125$ & 175,438 & \\
\hline
\end{tabular}

$\mathrm{AC}=$ Activated carbon

Table 11 value of isotherms parameters of nitrate removal

\begin{tabular}{cccccc}
\hline & Com-AC & DC-5-750 & DC-5-750M1 & DC-7-900 & DC-7-900M1 \\
\hline Langmuir & & & & & \\
Qm (mg/g) & 20,618 & 26,737 & 17,064 & 21,276 & 17,513 \\
K $_{\mathrm{L}}(\mathrm{L} / \mathrm{mg})$ & 0,8165 & 0,5165 & 0,8561 & 0,5437 & 1,2918 \\
$\mathrm{R}_{\mathrm{L}}$ & $0,109-0,0134$ & $0,1622-0,021$ & $0,1045-0,0128$ & $0,1553-0,02$ & $0,0718-0,0085$ \\
$\mathrm{R}^{2}$ & 0,9759 & 0,9772 & 0,9959 & 0,9813 & 0,9967 \\
Freundlich & & & & \\
$\mathrm{K}_{\mathrm{F}}(\mathrm{mg} / \mathrm{g})(1 / \mathrm{mg})^{1 / \mathrm{n}}$ & 2,454 & 4,4942 & 3,2072 & 4,744 & 1,8323 \\
$1 / \mathrm{n}(1 / \mathrm{mg})$ & 0,4648 & 0,3873 & 0,3552 & 0,322 & 0,4724 \\
$\mathrm{R}^{2}$ & 0,9264 & 0,9455 & 0,9901 & 0,9317 & 0,9583 \\
\hline
\end{tabular}

610 
Table 12 comparison of nitrate Langmuir maximum capacity with literature

\begin{tabular}{|c|c|c|c|c|c|}
\hline $\begin{array}{l}\text { Adsorbent } \\
\text { type }\end{array}$ & $\begin{array}{l}\text { Surface } \\
\text { area } \\
\left(\mathrm{m}^{2} / \mathrm{g}\right)\end{array}$ & $\begin{array}{l}\text { Solution } \\
\mathrm{pH}\end{array}$ & $\begin{array}{l}\text { Concentration } \\
\text { range }(\mathrm{mg} / \mathrm{l})\end{array}$ & $\underset{(\mathrm{mg} / \mathrm{g})}{\mathrm{q}_{\mathrm{m}}}$ & Reference \\
\hline $\begin{array}{l}\text { Sawdust } \\
\text { AC* with } \\
\text { KOH }\end{array}$ & 768 & 2 & $8,5-510$ & 25,499 & [51] \\
\hline $\begin{array}{l}\text { Commercial } \\
\text { AC }\end{array}$ & 1424 & 2 & $8,5-510$ & 19,549 & \\
\hline $\begin{array}{l}\text { Urea treated } \\
\text { AC }\end{array}$ & 192 & 2 & $8,5-680$ & 38,824 & [8] \\
\hline $\begin{array}{c}\text { Thermally } \\
\text { post- treat AC }\end{array}$ & 772 & 2 & $8,5-680$ & 25,499 & \\
\hline $\begin{array}{c}\mathrm{AC} \\
\text { oxidized with } \\
\text { CETAB } *\end{array}$ & 901 & 7 & $40-200$ & 21,51 & [25] \\
\hline $\begin{array}{r}\text { Metal } \\
\text { oxidized } \\
\text { biochar }\end{array}$ & 155,08 & - & $50-1500$ & 32,23 & [59] \\
\hline $\begin{array}{l}\mathrm{ZnCl}_{2} \text { olive } \\
\text { stone } \mathrm{AC}\end{array}$ & 1480 & 4 & $100-300$ & 5,525 & [5] \\
\hline $\begin{array}{c}\text { Municipal } \\
\text { sewage sludge } \\
\text { biochar }\end{array}$ & 2,82 & 2 & $20-100$ & 2,1127 & [60] \\
\hline $\begin{array}{l}\text { Commercial } \\
\text { AC }\end{array}$ & 603,209 & 2 & $10-90$ & 20,618 & $\begin{array}{l}\text { This } \\
\text { work }\end{array}$ \\
\hline DC-5-750 & 312,79 & 2 & $10-90$ & 26,737 & \\
\hline $\begin{array}{l}\text { DC-5- } \\
750 \mathrm{M} 2\end{array}$ & 282,22 & 2 & $10-90$ & 17,064 & \\
\hline
\end{tabular}

\section{$\mathrm{AC}^{*}=$ Activated carbon}

$\mathrm{CETAB}=$ cetyl trimethyl ammonium bromide

Nitrate Langmuir and Freundlich isotherms were used to investigate the nitrate removal process. The findings are presented in Table 11.

As predicted, the Langmuir isotherm described the process better than the Freundlich model, with a greater R2 for all adsorbents involved on a monolayer surface. The value of RL between 0 and 1 indicated that both sorbate adsorption was favourable on all sorbent surfaces of the Langmuir isotherm model, it is regarded as unfavourable if RL>1 [36], for Freundlich model adsorption intensity $(1 / n)$ value was less than 0,5 in all cases, indicating that sorbate was easily adsorbed, it is hardly adsorbed if $1 / \mathrm{n}>2$ [42]. 
It is worth noting that MR adsorption became more irreversible with increasing concentration since the RL value approached zero at higher concentration $[25,26]$. The published data are also compared to the present study's nitrate adsorption capacities in Table 12.To assess the effect of ionic strength, MR was diluted in $\mathrm{NaCl}$ solution with a concentration of $0.01 \mathrm{M}$ and $0,05 \mathrm{M}$ and the $\mathrm{pH}$ was adjusted at 4. As shown in Figure 23, presumably $\mathrm{Na}^{+}$cations competition and screening effect of $\mathrm{Cl}^{-}$anions at the external surface of adsorbent [54] caused adsorption capacity of oxidized SABC to dwindle narrowly with $\mathrm{NaCl}$ concentration change from $127,63 \mathrm{mg} / \mathrm{g}$ (without $\mathrm{NaCl}$ ) to $117,08 \mathrm{mg} / \mathrm{g}(0,05 \mathrm{M} \mathrm{NaCl})$ for DC-5-750M1 and $122,29 \mathrm{mg} / \mathrm{g}$ (without $\mathrm{NaCl}$ ) to $119,61 \mathrm{mg} / \mathrm{g}(0,05 \mathrm{M} \mathrm{NaCl})$ for DC-7-900M1, contrariwise Com-AC and unoxidized adsorbents (DC-5-750 and DC-7-900) increased with $\mathrm{NaCl}$ concentration augmentation from $121,08 \mathrm{mg} / \mathrm{g}$ to $129,42 \mathrm{mg} / \mathrm{g}, 114,43 \mathrm{mg} / \mathrm{g}$ without $\mathrm{NaCl}$ to $125,31 \mathrm{mg} / \mathrm{g}$ and $110,29 \mathrm{mg} / \mathrm{g}$ to $122,85 \mathrm{mg} / \mathrm{g}$ in presence of $0,05 \mathrm{M} \mathrm{NaCl}$ respectively, adsorption capacity upward trend could have been imputed arguably to dye aggregation drove by salt ions force [61].

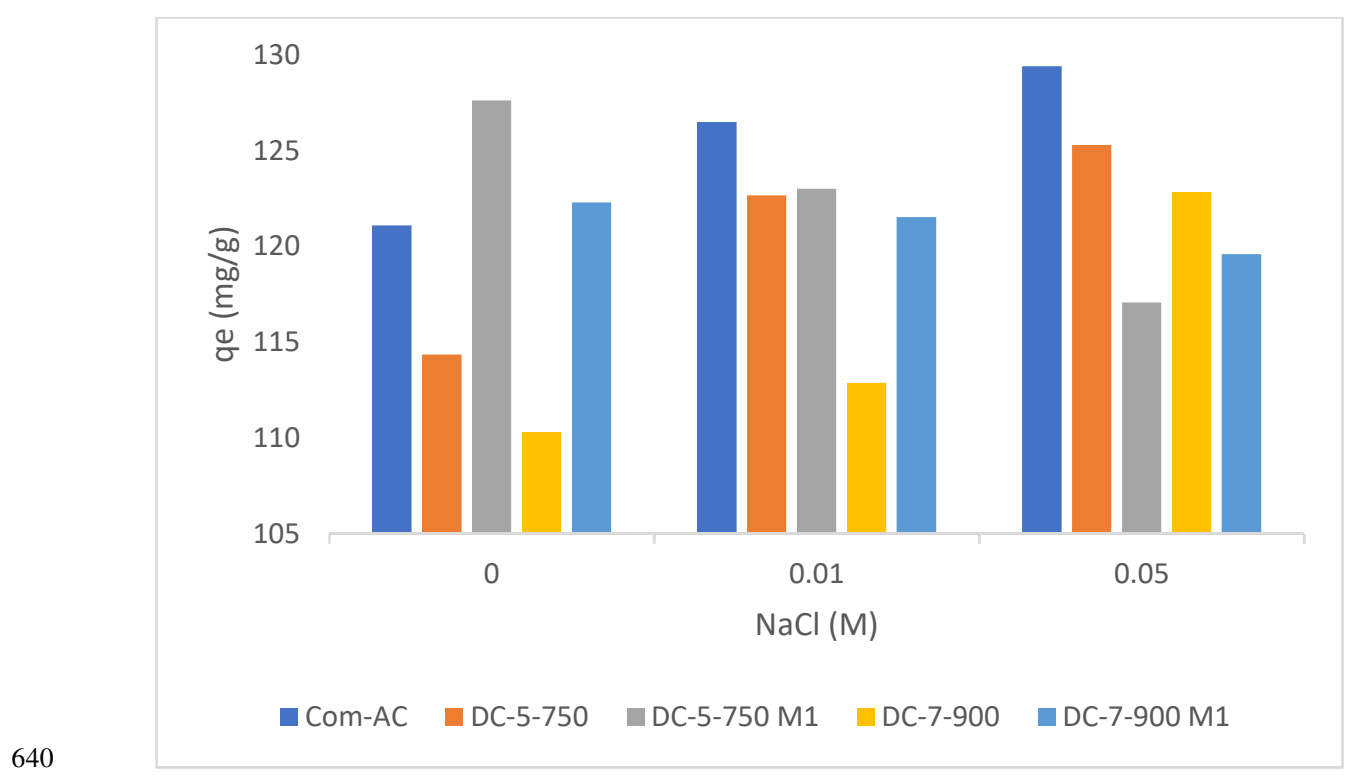

Figure 23 effect of ionic strength on MR uptake 


\subsection{Environmental consideration: toxicity characteristic leaching procedure}

645 The toxicity contaminant leaching procedure was carried out as described elsewhere $[39,62]$, and the element concentrations were determined using a PerkinElmer AA spectrometer. Table 13 shows the results of the TCLP test; in general, the concentration of leachable heavy metal in the pyrolyzed adsorbent was lower than the precursor due to the higher thermal stability of heavy metal acquired through pyrolysis $650 \quad[62]$.

However, after pyrolysis, SC-5-900 released more heavy metals ( $\mathrm{Fe}, \mathrm{Cr}$, $\mathrm{Co}$, and $\mathrm{Ni}$ ) than its precursors. This may be due to the disintegration of some stable inorganic minerals (primarily silicate and carbonate) from sludge during pyrolysis with temperature augmentation, which caused the liberation of the fixed metals from the lattice [17].

Table 13 Heavy metal concentration leached from precursors and sorbents

\begin{tabular}{|c|c|c|c|c|c|c|c|c|}
\hline & \multicolumn{8}{|c|}{ Elements (mg/l) } \\
\hline & $\mathrm{Cu}$ & $\mathrm{Zn}$ & $\mathrm{Pb}$ & $\mathrm{Ni}$ & $\mathrm{Co}$ & $\mathrm{Cr}$ & $\mathrm{Fe}$ & $\mathrm{Mn}$ \\
\hline $\mathrm{D}$ & 3,534 & 0,0498 & 18,99 & 0,329 & 0,0061 & 0,000 & 0,670 & 0,000 \\
\hline $\mathrm{S}$ & 3,228 & 0,0970 & 25,11 & 0,000 & 0,332 & 0,000 & 0,145 & 0,006 \\
\hline Discard Coal & 3,520 & 0,2773 & 27,46 & 0,000 & 0,336 & 0,000 & 0,000 & 0,005 \\
\hline Com-AC & 0,897 & 0,1238 & 0,58 & 0,073 & 0,713 & 0,575 & 0,000 & 0,068 \\
\hline SC-3-600 & 3,154 & 0,1247 & 24,93 & 4,064 & 0,326 & 0,000 & 0,000 & 0,007 \\
\hline SC-5-900 & 1,922 & 0,2474 & 20,09 & 4,236 & 0,752 & 1,555 & 17,092 & 2,798 \\
\hline DC-5-750 & 3,191 & 0,0379 & 24,99 & 0,000 & 0,279 & 0,000 & 0,000 & 0,003 \\
\hline DC-7-900 & 3,306 & 0,0294 & 24,81 & 0,000 & 0,489 & 0,000 & 0,000 & 0,000 \\
\hline
\end{tabular}




\section{Conclusion}

In this paper, two types of sewage sludge were used to make low-cost bioadsorbents: D, which was collected during the dissolved air flotation stage, and S, which was a mixture of primary and secondary sludge from the digestion and dewatering stages. The sewage sludge was mixed with waste coal before being activated with $\mathrm{KOH}$ and oxidized with APS. The ability of the synthesized bio-adsorbents to remove nitrate and MR was assessed and compared to that of industrial activated charcoal. The oxidation with APS influenced (i) the textural properties of bio-adsorbent derived from sludge $\mathrm{S}$ more negatively than those derived from $\mathrm{D}$, (ii) influenced organic composition only marginally as revealed by ultimate analysis, and (iii) induced the introduction of acidic functional groups as revealed by FT-IR and Raman spectroscopy analysis, respectively. Adsorbents' adsorption capability increased with time and initial concentrations of contaminants. The removal processes of nitrate and MR followed the pseudo second order kinetic model and the Langmuir isotherm reasonably well. At $\mathrm{pH}=2$ and $\mathrm{pH}=4$, nitrate and $\mathrm{MR}$ adsorption capacities were higher, respectively.

\section{References}

[1] Li, Yili, Li, Yanling, Li, L., Shi, X., Wang, Z., 2016. Preparation and analysis of activated carbon from sewage sludge and corn stalk. Adv. Powder Technol. 27, 684-691.

[2] Baloy, O., Sihaswana, D., Maringa, M., Sibande, J., Oelofse, S., Schubert, S., 2012. NATIONAL WASTE INFORMATION BASELINE REPORT. Department of Environmental Affairs, Pretoria.

[3] Herselman, J.E. and Snyman, H.G., 2009. Guidelines for the utilisation and disposal of wastewater sludge. Water Research Commission.

[4] Wu, C., Li, L., Zhou, H., Ai, J., Zhang, H., Tao, J., Wang, D., Zhang, W., 2021. Effects of chemical modification on physicochemical properties and adsorption behavior of sludge-based activated carbon. J. Environ. Sci. 100, 340-352.

[5] Nassar, H., Zyoud, A., El-Hamouz, A., Tanbour, R., Halayqa, N., Hilal, H.S., 2020. Aqueous nitrate ion adsorption/desorption by olive solid waste-based carbon activated using $\mathrm{ZnCl2}$. Sustain. Chem. Pharm. 18, 100335

[6] Ahmad, M.A., Ahmed, N.B., Adegoke, K.A., Bello, O.S., 2019. Sorption studies of methyl red dye removal using lemon grass (Cymbopogon citratus). Chem. Data Collect. 22, 100249.

[7] Yang, B., Liu, Y., Liang, Q., Chen, M., Ma, L., Li, L., Liu, Q., Tu, W., Lan, D., Chen, Y., 2019. Evaluation of activated carbon synthesized by one-stage and two- 
stage co-pyrolysis from sludge and coconut shell. Ecotoxicol. Environ. Saf. 170, 722-731.

[8] Nunell, G.V., Fernandez, M.E., Bonelli, P.R., Cukierman, A.L., 2015. Nitrate uptake improvement by modified activated carbons developed from two species of pine cones. J. Colloid Interface Sci. 440, 102-108.

[9] Li, Juan, Xing, X., Li, Jiao, Shi, M., Lin, A., Xu, C., Zheng, J., Li, R., 2018. Preparation of thiol-functionalized activated carbon from sewage sludge with coal blending for heavy metal removal from contaminated water. Environ. Pollut. 234, $677-683$

[10] dos Reis, G.S., Adebayo, M.A., Lima, E.C., Sampaio, C.H., Prola, L.D., 2016. Activated carbon from sewage sludge for preconcentration of copper. Anal. Lett. $49,541-555$.

[11]Tao, H.-C., Zhang, H.-R., Li, J.-B., Ding, W.-Y., 2015. Biomass based activated carbon obtained from sludge and sugarcane bagasse for removing lead ion from wastewater. Bioresour. Technol. 192, 611-617.

710 [12]Zhang, J., Shao, J., Jin, Q., Li, Z., Zhang, X., Chen, Y., Zhang, S., Chen, H., 2019. Sludge-based biochar activation to enhance $\mathrm{Pb}$ (II) adsorption. Fuel 252, 101-108.

[13]Park, J., Lee, S.-S., 2018. Adsorption of mercury by activated carbon prepared from dried sewage sludge in simulated flue gas. J. Air Waste Manag. Assoc. 68, 1077-1084.

[14]Devi, P., Saroha, A.K., 2017. Utilization of sludge based adsorbents for the removal of various pollutants: a review. Sci. Total Environ. 578, 16-33.

[15]Liang, Q., Liu, Y., Chen, M., Ma, L., Yang, B., Li, L., Liu, Q., 2020. Optimized preparation of activated carbon from coconut shell and municipal sludge. Mater. Chem. Phys. 241, 122327.

[16]Björklund, K., Li, L.Y., 2017. Adsorption of organic stormwater pollutants onto activated carbon from sewage sludge. J. Environ. Manage. 197, 490-497.

[17]Li, L.Y., Gong, X., Abida, O., 2019. Waste-to-resources: Exploratory surface modification of sludge-based activated carbon by nitric acid for heavy metal adsorption. Waste Manag. 87, 375-386.

725 [18]Zhang, G., Shi, L., Zhang, Y., Wei, D., Yan, T., Wei, Q., Du, B., 2015. Aerobic granular sludge-derived activated carbon: mineral acid modification and superior dye adsorption capacity. RSC Adv. 5, 25279-25286.

[19]Rehman, A., Park, M., \& Park, S. J. (2019). Current progress on the surface chemical modification of carbonaceous materials. Coatings, 9(2), 103.

[20] Bhatnagar, A., Hogland, W., Marques, M., \& Sillanpää, M. (2013). An overview of the modification methods of activated carbon for its water treatment applications. Chemical Engineering Journal, 219, 499-511.

[21] Radovic, L. R., Moreno-Castilla, C., \& Rivera-Utrilla, J. (2001). Carbon materials as adsorbents in aqueous solutions. Chemistry and physics of carbon, 227-406.

[22] Ang, T. N., Young, B. R., Taylor, M., Burrell, R., Aroua, M. K., Chen, W. H., \& Baroutian, S. (2020). Enrichment of surface oxygen functionalities on activated carbon for adsorptive removal of sevoflurane. Chemosphere, 260, 127496.

[23] Han, X., Lin, H., Zheng, Y., 2015. Adsorptive denitrogenation and desulfurization of diesel using activated carbons oxidized by (NH4) $2 \mathrm{~S} 2 \mathrm{O} 8$ under mild conditions. Can. J. Chem. Eng. 93, 538-548. 
[24]Li, X., Jiang, Y., Wang, P., Mo, Y., Li, Z., Yu, R., Du, Y., Zhang, X., Chen, Y., 2020. Effect of the oxygen functional groups of activated carbon on its electrochemical performance for supercapacitors. New Carbon Mater. 35, 232243.

[25] Mazarji, M., Aminzadeh, B., Baghdadi, M., Bhatnagar, A., 2017. Removal of nitrate from aqueous solution using modified granular activated carbon. J. Mol. Liq. 233, 139-148

[26] Khan, E.A., Shahjahan, Khan, T.A., 2018. Adsorption of methyl red on activated carbon derived from custard apple (Annona squamosa) fruit shell: Equilibrium isotherm and kinetic studies. J. Mol. Liq. 249, 1195-1211. https://doi.org/10.1016/j.molliq.2017.11.125

[27] Sheldrick, B. H. (Ed.). (1984). Analytical methods manual 1984 (p. 13). Ottawa, Ontario, Canada: Land Resource Research Institute.

[28] Boehm, H. P. (2002). Surface oxides on carbon and their analysis: a critical assessment. Carbon, 40(2), 145-149.

[29]Leng, L., Yuan, X., Huang, H., Shao, J., Wang, H., Chen, X., \& Zeng, G. (2015). Bio-char derived from sewage sludge by liquefaction: Characterization and application for dye adsorption. Applied Surface Science, 346, 223-231.

[30]Ding, G., Wang, B., Chen, L., Zhao, S., 2016. Simultaneous adsorption of methyl red and methylene blue onto biochar and an equilibrium modeling at high concentration. Chemosphere 163, 283-289.

[31]Diffo, B. K., Elimbi, A., Cyr, M., Manga, J. D., \& Kouamo, H. T. (2015). Effect of the rate of calcination of kaolin on the properties of metakaolin-based geopolymers. Journal of Asian Ceramic Societies, 3(1), 130-13

[32] Reig, F. B., Adelantado, J. G., \& Moreno, M. M. (2002). FTIR quantitative analysis of calcium carbonate (calcite) and silica (quartz) mixtures using the constant ratio method. Application to geological samples. Talanta, 58(4), 811-821.

[33]Fan, S., Tang, J., Wang, Y., Li, H., Zhang, H., Tang, J., ... \& Li, X. (2016). Biochar prepared from co-pyrolysis of municipal sewage sludge and tea waste for the adsorption of methylene blue from aqueous solutions: kinetics, isotherm, thermodynamic and mechanism. Journal of Molecular Liquids, 220, 432-441.

[34] Al-Malack, M. H., \& Dauda, M. (2017). Competitive adsorption of cadmium and phenol on activated carbon produced from municipal sludge. Journal of Environmental Chemical Engineering, 5(3), 2718-2729.

775 [35] Gupta, A., Garg, A., 2015. Primary sewage sludge-derived activated carbon: characterisation and application in wastewater treatment. Clean Technol. Environ. Policy 17, 1619-1631.

[36] Devi, P., Saroha, A.K., 2016. Improvement in performance of sludge-based adsorbents by controlling key parameters by activation/modification: A critical review. Crit. Rev. Environ. Sci. Technol. 46, 1704-1743.

[37] Hadi, P., Xu, M., Ning, C., Lin, C.S.K., McKay, G., 2015. A critical review on preparation, characterization and utilization of sludge-derived activated carbons for wastewater treatment. Chem. Eng. J. 260, 895-906.

[38] Xu, G., Yang, X., \& Spinosa, L. (2015). Development of sludge-based adsorbents: Preparation, characterization, utilization and its feasibility assessment. Journal of Environmental Management, 151, 221-232. 
[39]Huang, H. J., Yang, T., Lai, F. Y., \& Wu, G. Q. (2017). Co-pyrolysis of sewage sludge and sawdust/rice straw for the production of biochar. Journal of Analytical and Applied Pyrolysis, 125, 61-68.

790 [40]Lee, Y. E., Kim, I. T., \& Yoo, Y. S. (2018). Stabilization of high-organic-content water treatment sludge by pyrolysis. Energies, 11(12), 3292.

[41]Lu, H., Zhang, W., Wang, S., Zhuang, L., Yang, Y., \& Qiu, R. (2013). Characterization of sewage sludge-derived biochars from different feedstocks and pyrolysis temperatures. Journal of Analytical and Applied Pyrolysis, 102, 137-143.

[42] Collins, J., Zheng, D., Ngo, T., Qu, D., Foster, M., 2014. Partial graphitization of activated carbon by surface acidification. Carbon 79, 500-517.

[43] Aburub, A., Wurster, D.E., 2006. Phenobarbital interactions with derivatized activated carbon surfaces. J. Colloid Interface Sci. 296, 79-85.

[44] Daud, W.M.A.W., Houshamnd, A.H., 2010. Textural characteristics, surface chemistry and oxidation of activated carbon. J. Nat. Gas Chem. 19, 267-279.

[45] Smith, K., Fowler, G., Pullket, S., Graham, N.D., 2009. Sewage sludge-based adsorbents: a review of their production, properties and use in water treatment applications. Water Res. 43, 2569-2594.

[46] Tan, K.L., Hameed, B.H., 2017. Insight into the adsorption kinetics models for the removal of contaminants from aqueous solutions. J. Taiwan Inst. Chem. Eng. 74, 25-48. https://doi.org/10.1016/j.jtice.2017.01.024

[47] Nassar, H., Zyoud, A., El-Hamouz, A., Tanbour, R., Halayqa, N., \& Hilal, H. S. (2020). Aqueous nitrate ion adsorption/desorption by olive solid waste-based carbon activated using ZnCl2. Sustainable Chemistry and Pharmacy, 18, 100335.

[48] Xia, F., Yang, H., Li, L., Ren, Y., Shi, D., Chai, H., Ai, H., He, Q., Gu, L., 2020. Enhanced nitrate adsorption by using cetyltrimethylammonium chloride preloaded activated carbon. Environ. Technol. 41, 3562-3572.

[49] Ahmad, M.A., Ahmad, N., Bello, O.S., 2015. Modified durian seed as adsorbent for the removal of methyl red dye from aqueous solutions. Appl. Water Sci. 5, 407423. https://doi.org/10.1007/s13201-014-0208-4

[50] Bhatnagar, A., Ji, M., Choi, Y., Jung, W., Lee, S., Kim, S., Lee, G., Suk, H., Kim, H., Min, B., 2008. Removal of nitrate from water by adsorption onto zinc chloride treated activated carbon. Sep. Sci. Technol. 43, 886-907.

[51] Nunell, G., Fernández, M., Bonelli, P., Cukierman, A., 2012. Conversion of biomass from an invasive species into activated carbons for removal of nitrate from wastewater. Biomass Bioenergy 44, 87-95.

[52] Gokce, Y., Aktas, Z., 2014. Nitric acid modification of activated carbon produced from waste tea and adsorption of methylene blue and phenol. Appl. Surf. Sci. 313, 352-359.

825 [53] Souza, C., Majuste, D., \& Ciminelli, V. S. T. (2014). Effects of surface properties of activated carbon on the adsorption mechanism of copper cyanocomplexes. Hydrometallurgy, 142, 1-11.

[54] Jung, K., Lee, S.Y., Lee, Y.J., 2019. Optimized preparation of activated carbon from municipal sewage sludge and application to the adsorption of azo dye from aqueous solutions. Environ. Prog. Sustain. Energy 38, S267-S276.

[55] Afroze, S., Sen, T.K., 2018. A Review on Heavy Metal Ions and Dye Adsorption from Water by Agricultural Solid Waste Adsorbents. Water. Air. Soil Pollut. 229, 225. https://doi.org/10.1007/s11270-018-3869-z 
[56] Guo, T., Yao, S., Chen, H., Yu, X., Wang, M., Chen, Y., 2017. Characteristics and adsorption study of the activated carbon derived from municipal sewage sludge. Water Sci. Technol. 76, 1697-1705.

[57] Yagub, M.T., Sen, T.K., Afroze, S., Ang, H.M., 2014. Dye and its removal from aqueous solution by adsorption: a review. Adv. Colloid Interface Sci. 209, 172184.

840 [58] Saleh, T.A., Al-Absi, A.A., 2017. Kinetics, isotherms and thermodynamic evaluation of amine functionalized magnetic carbon for methyl red removal from aqueous solutions. J. Mol. Liq. 248, 577-585.

[59]Long, L., Xue, Y., Hu, X., Zhu, Y., 2019. Study on the influence of surface potential on the nitrate adsorption capacity of metal modified biochar. Environ. Sci. Pollut. Res. 26, 3065-3074.

[60] Revilla, P.N.D., Maguyon-Detras, M.C., Migo, V.P., Alfafara, C.G., 2020. Nitrate removal from aqueous solution by adsorption using municipal solid waste-derived activated biochar. Presented at the IOP Conference Series: Materials Science and Engineering, IOP Publishing, p. 012135.

[61] Al-Degs, Y. S., El-Barghouthi, M. I., El-Sheikh, A. H., \& Walker, G. M. (2008). Effect of solution $\mathrm{pH}$, ionic strength, and temperature on adsorption behavior of reactive dyes on activated carbon. Dyes and pigments, 77(1), 16-23.

[62] Xue, Y., Wang, C., Hu, Z., Zhou, Y., Xiao, Y., \& Wang, T. (2019). Pyrolysis of sewage sludge by electromagnetic induction: Biochar properties and application in adsorption removal of $\mathrm{Pb}$ (II), Cd (II) from aqueous solution. Waste Management, $89,48-56$. 


\section{Declarations}

\section{Funding}

Not applicable

\section{Conflicts of interest/Competing interests}

The authors have no affiliation with any organization with a direct or indirect financial interest in the subject matter discussed in the manuscript

Availability of data and material

Some of the data will be made available upon the journal acceptance

915

\section{Code availability}

Not applicable

\section{Authors' contributions}

All authors have participated in (a) conception and design, or analysis and interpretation of the data; (b) drafting the article or revising it critically for important intellectual content; and (c) approval of the final version

Ethics approval

Not applicable

\section{Consent to participate}

Not applicable

Consent for publication

$930 \quad$ Not applicable 